\title{
Sivas Kongresi (4-11 Eylül 1919) Delegelerine Dair Bazı Tespitler $^{*}$
}

\section{Determinations About the Delegates of The Sivas Congress (4-11 September 1919)}

\author{
Fatih M. Sancaktar**
}

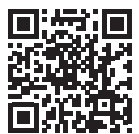

*Bu çalışma 2016 yılında Büyük Millet Meclisi Başkanlığı ve Kültür ve Turizm Bakanlığı için hazırlanan Sivas Kongresi Müzesi adlı proje kapsamında Sivas Kongresi delegelerine dair yapılan bir çalışmanın ve Milli Mücadelenin 100 . Yılı Sempozyumu'nda (27 Kasım 2019-Istanbul Aydın Üniversitesi) sunulan tebliğin genişletilmiş ve yenilenmiş halidir.

**Doç. Dr., İstanbul Üniversitesi, Edebiyat Fakültesi, Tarih Bölümü, İstanbul, Türkiye

\section{ORCID: F.M.S. 0000-0002-5501-4982}

Sorumlu yazar/Corresponding author: Fatih M. Sancaktar,

İstanbul Üniversitesi, Edebiyat Fakültesi, Tarih Bölümü, İstanbul, Türkiye

E-posta/E-mail: fatihsancaktar@yahoo.com

Başvuru/Submitted: 10.06 .2020 Revizyon Talebi/Revision Requested: 24.06.2020

Son Revizyon/Last Revision Received: 06.07.2020

Kabul/Accepted: 12.07 .2020

\section{Atıf/Citation:}

Sancaktar, Fatih M. "Sivas Kongresi (4-11 Eylül 1919) Delegelerine Dair Bazı Tespitler." Tarih Dergisi - Turkish Journal of History, 71 (2020): 473-496.

https://doi.org/10.26650/TurkJHist.2020.022

\section{ÖZ}

Tam İstiklal görüşünü savunanlar açısından, Milli Mücadele tarihinin en önemli dönüm noktalarından biri Sivas Kongresi'dir. 4-11 Eylül 1919 tarihleri arasında toplanan bu kongrede alınan kararlar, yeni Türk devletine giden sürecin ve Anadolu Hareketi'nin karakter ve şeklini belirlemiştir. Sivas Kongresi'nde alınan kararlarla Anadolu Hareketi, artık bütün ülke için ve temsil ettiği millet adına çaba sarf edecekti. Ancak böylesine önemli özelliğe sahip Sivas Kongresi delegelerine dair yazılan hatıra ve telif eserlerde, birtakım sorunların olduğu bilinmektedir. Bu sorunlar genel olarak kongreyi katılan delegelerin isimleri, sayısı ve temsil ettikleri şehirleri şeklinde sıralamak mümkündür. Bu çalışma, farklı bir yaklaşım üzerinden hareketle, Sivas Kongresi delegelerine dair ifade edilen sorunları daha belirgin şekilde ortaya koyma ve bir nebze de olsa açıklık getirme amacı taşımaktadır. Bu yüzden çalışma yöntem olarak, belirlenen bazı kriterler çerçevesinde doğrudan doğruya kongre tutanak ve belgelerini inceleme esasını benimsemiştir.

Anahtar sözcükler: Sivas Kongresi, Delegeler, Anadolu Hareketi

\section{ABSTRACT}

From the point of view of defenders of full independence, one of the most important turning points in the history of the National Struggle was the Sivas Congress. The decisions taken at this Congress, which was convened between 4-11 September 1919, determined the character and shape of the process leading to the New Turkish State and the Anatolian Movement. In the light of the decisions made at the Sivas Congress, the Anatolian movement would make efforts on behalf of the whole country and of the nation it represents. However, it is known that there are some mistakes in the memoirs and copyrighted works written about the Sivas Congress delegates. These issues are mainly regarding the names and number of delegates attending the convention and the cities they represent. This study aims to explain the issues expressed about the delegates of the Sivas Congress in a more specific way and to clarify them to some extent. Therefore, this study is based on a direct examination of the minutes and documents of the Congress within the framework of certain criteria.

Keywords: The Sivas Congress, Delegates, The Anatolian Movement 


\section{Giriş}

Milli Mücadele süreci, 30 Ekim 1918 tarihli Mondros Mütarekesi'nden itibaren anbean gün gün takip edilmeli, gelişmeler ulusal ve uluslararası durumlar dikkate alınarak, kendi bağlamı içinde değerlendirilmelidir. Bu manada I. Dünya Savaşı ve Mondros Mütarekesi’nin getirdiği sorunların çözümüne dair Mandacı, Himayeci ve Bölgesel Kurtuluş ${ }^{1}$ reçetelerinin muarızı olarak ortaya çıkan Tam Ístiklal görüşü de kendi gerçekliği içinde var olmuştur. Türkiye Cumhuriyeti Devleti'nin kuruluşuna giden zaman dilimi içinde, Tam İstiklal görüşünün, bir başka ifade ile Milli Mücadele'nin önemli dönüm noktaları öne çıkmaktadır. Ancak bu dönüm noktalarındaki gelişmeler, sadece yeni Türk devletinin ortaya çıkmasını değil, aynı zamanda şekillenmesini ve ruh kazanmasını da biçimlendirmiştir. 4-11 Eylül 1919 tarihlerin arasında toplanan Sivas Kongresi, bu açıdan da değerlendirilmelidir. Bu noktada Sivas Kongresi, I. TBMM'nin açılmasıyla Tam İstiklal düşüncesi ve taraftarlarının genel kabul göreceği döneme kadar, en önemli adımlarından biri olmuştur. Nitekim Sivas Kongresi, niteliği, temsil edilen şehirler ve alınan kararlar açısından Osmanlı coğrafyasında yeni bir iktidar merkezi olma yolunda önemli bir adım idi. Bu yüzden Türkiye'nin geleceğine dair alınan genel kararların yanı sıra toplanma şekli, şartları ve katılımcıların özellikleri, Sivas Kongresi'ni çok önemli ve değerli kılmıştır. Yine Mondros Mütarekesi'nin hemen ardından Anadolu coğrafyasının birçok yerinde toplanan kongreleri ve direniş hareketlerini, yapılarını birleştirme amacı taşıması, Sivas Kongresi'nin bütünleyici ve toparlayıcı özelliğinden kaynaklanmaktaydı. Bu bütünleyici tavır, Milli Mücadele Hareketi'nin lider kadrosunun amaç ve hareket tarzından kaynaklanmıştır. Bu noktada böyle bir politika ve örgütlenme şeklini benimseyen delegelerin cesaret ve basiretleri unutulmamalıdır.

Yukarıda ifade edilen bu özelliklere istinaden Sivas Kongresi farklı yönleriyle birçok hatırada doğrudan veya dolaylı şekilde konu edildiği gibi, önemli bilimsel araştırma ve çalışmaların da öznesi olmuştur. Bu çalışmada bahsi geçen hatıraların ve araştırmaların öne çıkanları kullanılmıştır. Ancak böylesine önem taşıyan Sivas Kongresi'ne dair birçok hatıra yayınlanmış ve araştırma yapılmış olmasına rağmen, delegelerin isimleri, temsil yerleri gibi hususlarda bazı yönlerden ciddi sorunlar, hata, çelişki, farklılık ve eksiklikleri vardır. Bu durum kongreye katılanlar veya dönemi yaşayanlarca kaleme alınan hatıralarda da mevcuttur. Özellikle kongre delegelerinin isimlerindeki ve temsil edilen şehir adlarındaki farklılıklar, çoğu kez ilk anda göze çarpmaktadır. Bu meyanda bu farklılıkların, hata ve eksikliklerin, günümüze kadar yapılan çalışmalarla karşılaştırılarak ortaya çıkarılması, Sivas Kongresi'nin anlaşılmasına ve kongreye dair soruları cevaplamaya imkân sunacaktır.

1 Mustafa Kemal Atatürk, Nutuk, I, MEB, İstanbul 1993, s. 2-7, 11-12; Mandacı, Himayeci ve Bölgesel Kurtuluş görüşlerine dair geniş bilgi için bkz. Bülent Tanör, Türkiye'de Kongre İktidarları (1918-1920), YKY, İstanbul 1998. 
Bu yüzden bu çalışmada, delegelerle ilgili daha doğru bilgiler elde etmek için öncelikle bazı kriterler oluşturulmaya çalışılmıştır. Bu noktada tutanak ve belgeler, temel dayanak noktası, karşılaştırmalarda ilk ölçüt olmuştur. Özellikle Sivas Kongresi orijinal tutanak ve belgelerinin yayınlaması, bu çalışmanın ilk el kaynaklardan ortaya konulmasına önemli katkı sağlamıştır. Bu yönüyle çalışma Sivas Kongresi orijinal tutanaklarını kullanarak kendi içinde bir tutarlılık yakalanmayı amaçlamıştır². Bu meyanda Sivas İl Kültür Müdürlüğü’nce hazırlanan Orijinal Kongre tutanakları içeren 4 Eylül 1919 Sivas Kongresi, Tutanak ve Belgeleri adlı CD ve bütün Sivas Kongresi tutanaklarını karşılaştırarak basılı hale getiren Recep Toparlı'nın Sivas Kongresi Tutanakları ve Belgeleri ${ }^{3}$ isimli çalışmalar incelenmiştir.

$\mathrm{Bu}$ eserlerde delegelere dair bilgiler, Sivas Kongresi'nde konuşma yapanlar, takrir verenler, ismi geçenler şeklinde sınıflandırılarak tespit edilmeye çalışılmıştır. Daha sonra bu tespitler dikkate alınarak hatıralar ve telif eserlerle karşılaştırma yoluna gidilmiştir. Kaynaklar arasında tereddüde neden olan delege adları ve temsil yerlerine öncelik verilerek karşılaştırmalı çizelgeler ortaya konulmuştur. Dolayısıyla dönemin hatıraları ve Sivas Kongresi ile ilgili yapılan telif çalışmalar da bu yönüyle çalışmaya kaynaklık etmiştir. Böylece tutanaklar dikkate alınarak yukarıda ifade edilen kriterler üzerinden kongre delegelerinin tespitini ve kongre esnasında konuşmalara ve önergelere katkısını belirtmeye çalışılacaktır. Bu noktada çalışmanın temel amacı ve problemi, Sivas Kongresi ile ilgili hatıra, doküman ve çalışmaları karşılaştırarak, belirli kriterler çerçevesinde kongre delegelerine dair birtakım hususları tespit edebilmektir. Bu yüzden Sivas Kongresi süreci, faaliyetleri ve kararları doğrudan doğruya bu çalışmanın konusu değildir.

\section{A. Sivas Kongresi Yolunda}

Mustafa Kemal Paşa 19 Mayıs 1919'da Samsun'a çıkmasından çok kısa bir süre sonra Merzifon, Amasya ve Havza'daki bazı şikâyetlerin incelenmesi ve gerekli tedbirlerin alınması için “karargâhını” Havza’ya taşımıştır. Mustafa Kemal Paşa 25 Mayıs 1919’da

2 Sivas Kongresi tutanaklarının Cumhurbaşkanlığı Kütüphanesi, Türk Tarih Kurumu Kütüphanesi ve Sivas Atatürk Kongre ve Etnografya Müzesi nüshaları bulunmaktadır. Recep Toparl1, Sivas Kongresi Tutanaklarl ve Belgeleri, Cumhuriyet Üniversitesi Sivas Araştırma ve Uygulama Merkezi Yayınları, Sivas 2014, s. IX-X.

34 Eylül 1919 Sivas Kongresi Tutanak ve Belgeleri, Sivas 2009, haz. Kadir Pürlü, Sivas İl Kültür Müdürlüğü. Bu CD’de Osmanlı Türkçesiyle Sivas Kongresi'ne dair tutanaklar, belgeler, fotoğraflar bulunmaktadır. Ayrıca tutanakların ve belgelerin Latin harfli yazımları da kaydedilmiştir. Recep Toparlı, Sivas Kongresi Tutanaklarl ve Belgeleri, CÜSAM, Sivas 2014. Bu çalışmada Sivas Kongresi’ne dair bütün tutanaklar ve belgeler, Osmanlı ve Latin harfli halleri karşılaştırılarak ortaya konulmuştur. Sivas Kongresi'ne dair oldukça önemli katkı sağlayacak bir çalışmadır. Birbirine benzeyen her iki çalışma, bu araştırmada yoğun bir şekilde karşılaştırılmalı olarak kullanılmıştır. $\mathrm{Bu}$ çalışmanın dipnotlarında kongre tutanaklarından kaynak verildiğinde, her iki çalışma da esas alınmış ve Sivas Kongresi Tutanakları şeklinde gösterilmiştir. Ayrıca Recep Toparlı'nın Sivas Kongresi ile ilgili Latin harfli çalışmaları da bulunmaktadır. Sivas Kongresi Tutanakları, haz. Recep Toparlı, Sivas Vilayet Kitaplığı, Sivas 2015; Sivas Kongresi Belgeleri, haz. Recep Toparlı, Sivas Vilayet Kitaplığı, Sivas 2015. Sivas Kongresi'ne dair ilk tutanaklar Uluğ İğdemir tarafından sadeleştirilerek, Türk Tarih Kurumu’ndaki kopya kongre tutanakları üzerinden yapılmıştır. Uluğ İğdemir, Sivas Kongresi Tutanakları, 3. Baskı, TTK, Ankara 1999.

4 Dokuzuncu Ordu Kıta'atı Müfettişi Fahr-i Yaver-i Hazreti- Şehriyârî Mirliva Mustafa Kemal'den Dâhiliye Nezaretine gönderilen 24 Mayıs 1919 tarihli telgraf, BOA, DH.ŞFR, 631/106-1, lef 1. 
Havza'ya varmıştır. Havza' da yetkisi dâhilindeki vilayetler ve sancaklardaki askeri ve idari birimlere 28 Mayıs 1919' da telgrafla bir genelge yayınlamıştır. Bu telgrafta Osmanlı Devleti için İzmir ve Manisa işgallerinin ortaya çıkardığı tehlikenin "ref' ve izalesini bütün medeni milletlerle büyük devletler"den beklendiğine dair "tezâhürat-1 milliye"yi gösteren protesto mitingleri düzenlemesi istenmiştir. Mustafa Kemal Paşa birçok kurum ve resmi hüviyete sahip kişilere telgraf çekmiştir 5 .

Mustafa Kemal Paşa 12 Haziran 1919'da Amasya'ya gelmiş ve şehrin önde gelenleri ve halk ile görüşmelerde bulunmuştur. Bu girişimlerin ardından 22 Haziran 1919'da Amasya Tamimi yayınlanmıştır ${ }^{6}$. Böylece Sivas’ta “milli” ve “umumi” bir kongrenin “serian” yapılması düşüncesi daha Milli Hareket'in başlangıç evresinde, Erzurum Kongresi (23 Temmuz - 7 Ağustos 1919) gerçekleşmeden önce, Mustafa Kemal Paşa ve arkadaşları tarafından bu genelge ile ilan edilmişti ${ }^{7}$. Osmanlı mülkî ve askerî makamlara gönderilen 4 maddelik bu genelgeye göre, vatanın bütünlüğü ve ülkenin istiklali "tehlike altında idi ve İtilaf Devletlerinin etkisi ve kontrolü altındaki "hükümet-i merkeziye", yani İstanbul sorumluluklarını ve görevlerini yerine getirememekteydi. Bu yüzden “Anadolu'nun bi'l-vücuh en emin mahalli” Sivas'ta, "milletin istiklalini" kendi eline alacağı ve "sada-yı hukukunu" dünyaya duyuracağı millî bir kongrenin hızlı bir şekilde toplanması kararı alınmıştı. Sivas’taki bu kongreye bütün Osmanlı Vilayetlerindeki sancakları temsilen ${ }^{8}$ ve "fırka ihtilafı" gözetmeksizin "muktedir ve milletin itimadına” sahip “üç kadar zat” delege gönderilecekti. Ayrıca 10 Temmuz 1919'da toplanması planlanan Erzurum Kongresi üyelerinin uygun gördükleri bir zamanda Sivas Kongresi'ne katılacağı duyurulmuştur'. Bu genelgenin ve kelimelerin kaleme alındığı süreç dikkate alındığında, Sivas’ta bir kongre toplanması ile ilgili karar, milletin iradesini dikkate alan bir yaklaşımla, Mondros Mütarekesi sonrası Osmanlı Devleti'ne önerilecek sulha bir itiraz ve reva görülen işgallerin kabul edilemeyeceğine dair bir başkaldırı idi.

Amasya Tamimi ve Sivas'ta milletin temsilcilerinin bir araya geleceği genel kongrenin toplanmasına dair ortaya konulan irade, İtilaf Devletleri yetkililerini ve Damat Ferit Paşa Hükümeti'ni harekete geçirmiştir. Önce Mustafa Kemal Paşa ikna edilerek İstanbul'a geri dönmesini sağlamak istenmiş, daha sonra ise askerlik mesleğinden azletme yolu

5 Milli Egemenlik Belgeleri, TBMM Yayınları, Ankara 2015, s. 6-7; Mustafa Kemal Atatürk, a.g.e., s. 22, 26-29.

6 Amasya Tamimi duyurulmadan önce Refet Bey (Bele), Mersinli Cemal Paşa, Kazım Karabekir gibi kişilerle görüşmeler, fikir teatisi yapılmıştır. Tamim'de Mustafa Kemal Paşa ile birlikte Ali Fuat (Cebesoy), Hüseyin Rauf (Orbay), Hüsrev (Gerede), Kazım (Dirik)'in imzaları bulunmaktadır. Milli Egemenlik Belgeleri, s. 10, 12. Ayrıca bkz. Osman Akandere, "Milli Mücadelenin Başlarında Mustafa Kemal Paşa'nın Sine-i Millet Düşüncesi ile Askerlikten İstifa Öncesi ve Sonrası Kendisine Gösterilen Bağl1lıklar", Selçuk Üniversitesi Türkiyat Araştırmaları Dergisi, sayı 11, Konya 2002, s. 262-263.

7 Sivas Kongresi'nin 21 Haziran 1919 tarihinde toplanmasına dair karar için bkz. Mustafa Kemal Atatürk, a.g.e., III (Vesikalar), s. 947.

8 Osmanlı Meclis-i Mebusanı için milletvekilliği seçim bölgesi de Sancak (Liva) idi. Selda Kılıç, “1876 Meclis-i Mebusanı ve Seçim Hazırlıkları", OTAM, sayı 30, Ankara 2011, s. 29.

9 Milli Egemenlik Belgeleri, s. 9-12. 
izlenmiştir ${ }^{10}$. Mustafa Kemal Paşa, Tokat, Sivas, Erzincan üzerinden daha önce kongre kararı alınan Erzurum'a Rauf Bey ile birlikte hareket etmiştir. 3 Temmuz 1919'da Mustafa Kemal Paşa ve beraberindeki heyet Erzurum'a varmıştır ${ }^{11}$. Bu noktada Damat Ferit Paşa Hükümeti, Anadolu'daki hareketlenmeler üzerindeki baskısını artırmak istemiştir. Bu yüzden Damat Ferit Paşa Hükümeti, Erzurum'a varan Mustafa Kemal Paşa'y1 8 Temmuz 1919'da askerlikten azletme kararı almıştır. Bu kararın ardından Mustafa Kemal Paşa ise "silk-i askeriyeden" istifa etmiştir ${ }^{12}$.

Vilayet-i Şarkiye Müdafaa-i Hukuk-ı Milliye Cemiyeti Erzurum Şubesi, Trabzon Muhafaza-ı Hukuk-ı Milliye Cemiyeti ve Kars Milli Şurası'nın girişimleriyle daha önceden alınan karar çerçevesinde Erzurum Kongresi, gecikmeli de olsa 23 Temmuz 1919'da toplanmıştır. Erzurum Kongresi'ne Erzurum (24), Trabzon (17), Sivas (11), Bitlis (3), Van (2) vilayetlerinden olmak üzere toplam 57 delege katılmıştır. Mustafa Kemal Paşa önce kongre delegesi ve daha sonra kongre başkanı seçilmiştir ${ }^{13}$. Kongre boyunca yapılan tartışmaların ardından alınan kararlar ve toplanma gerekçesi 10 maddelik bir beyanname ile 7 Ağustos 1919'da ilan edilmiştir. Trabzon vilayeti, Canik Sancağı ve Vilâyât-1 Şarkiye'nin (Erzurum, Sivas, Diyarbakır, Elazığg, Van, Bitlis) birbirinden ve "câmia-i Osmaniyeden" ayrılmaz bir bütün olduğu, "Osmanlı vatanının” bütünlüğü, saltanat ve hilafet için Kuvva-i Milliye'nin “amil ve irade-i milliyeyi hâkim” kılma temeli üzerine çalışılacağı vurgulanmıştır. Kongre kararlarını takibi ve yürütülmesi için icra makamı hüviyetini taşıyan Heyet-i Temsiliye oluşturulmuş ve Mustafa Kemal Paşa bu yeni heyetin başkanı seçilmiştir ${ }^{14}$.

10 İngiliz Yüksek Komiseri Calthorpe'dan Hariciye Nezaretine gönderilen 8 Haziran 1919 tarihli yazı, BOA, HR. SYS, 2608/6, lef 1; 23 Haziran 1919 tarihli Meclis-i Vükela Mazbatası, BOA, MV, 216/54; Dâhiliye Nezaretinden Diyarbakır, Ankara, Erzurum, Sivas, Trabzon, Van, Kastamonu, Bitlis, Mamuretülaziz Vilayetleriyle Erzincan ve Canik Mutasarrıflıklarına gönderilen 23 Haziran 1919 tarihli şifre, BOA, DH.ŞFR, 100/174; Hariciye Nezaretinden Sadarete gönderilen 26 Haziran 1919 tarihli yazı, BOA, BEO, 4581/343541-15, lef 1.

11 Sivas Vilayetinden Dâhiliye Nezaretine gönderilen 26 Haziran 1919 tarihli şifre, BOA, DH.ŞFR, 635/88-1, lef 1, 2; Sivas Vilayetinden Dâhiliye Nezaretine gönderilen 20 Temmuz 1919 tarihli șifre, BOA, DH.ŞFR, 638/371; Erzincan Mutasarrıflığından Dâhiliye Nezaretine gönderilen 30 Temmuz 1919 tarihli şifre, BOA, DH.ŞFR, 636/24-1, lef 1; Mustafa Bostanc1, “Milli Mücadelede Erzurum Kongresi ve Kararları”, Nevşehir Hacı Bektaş Veli Üniversitesi Sosyal Bilimler Enstitüsü Dergisi, say1 4, Nevşehir 2015, s. 187.

128 Temmuz 1919 tarihli Meclis-i Vükela Mazbatası, BOA, MV, 251/34, lef 2; Dâhiliye Nezaretinden Diyarbakır Vilayetine gönderilen 9 Temmuz 1919 tarihli şifre, BOA, DH.ŞFR, 101/19-36; Dâhiliye Nezaretinden Sivas, Bitlis, Van, Erzurum Vilayetlerine gönderilen 19 Temmuz 1919 tarihli şifre, BOA, DH.ŞFR, 101/19-106, lef 1; Dâhiliye Nezaretinden Sivas Vilayetine gönderilen 29 Haziran 1919 tarihi şifre, BOA, DH.ŞFR, 100/203, lef 1; Mazhar Müfit Kansu, Erzurum 'dan Ölümüne Kadar Atatürk’le Beraber, I, TTK, Ankara 1988, s. 14-15, 36-41.

13 Erzurum Kongresi'ne katılan üye sayısı çalışmalarda farklı verilmektedir. Üye sayısı 53, 54 ve 57 şeklinde gösterilmektedir. Erzurum Vilayeti (Erzurum Merkez, Bayburt, Hınıs, İspir, Kığı, Narman, Hasankale, Tercan, Tortum, Yusufeli, Doğubeyazıd, Diyadin, Karaköse, Erzincan Kuruçay, Pülümür, Refahiye, Eleşkirt), Trabzon Vilayeti (Trabzon Merkez, Gümüşhane, Kelkit, Şiran, Maçka, Rize, Of, Sürmene, Akçaabat, Vakfikebir, Giresun, Tirebolu, Ordu), Sivas Vilayeti (Sivas Merkez, Amasya, Tokat, Suşehri, Sara, Mesudiye, Reşadiye, Şebinkarahisar, Alucra, Koyulhisar), Bitlis Vilayeti (Bitlis Merkez, Siirt) ve Van Vilayeti temsilcileri idi. Mahmut Goloğlu, Erzurum Kongresi, Ankara 1968; Selami Kılıç "Mustafa Kemal (Atatürk) ve Erzurum Kongresi”, Atatürk Dergisi, II, sayı 1, Erzurum 1997, s. 91.

14 Milli Egemenlik Belgeleri, s. 15-22; 24 Ağustos 1919'da Erzurum Valiliğine sunulan yazıda Mustafa Kemal, Rauf Bey, Raif Efendi, İzzet Bey, Servet Bey, Şeyh Fevzi Efendi, Bekir Sami Bey, Sadullah Efendi, Hacı Musa Bey Heyet-i Temsiliye üyeleridir. Mustafa Bostancı, a.g.m., s. 195. 
Kongreden sonra Mustafa Kemal Paşa bir müddet daha Erzurum'da kalmıştır. Ardından 9 arkadaşı ile birlikte Erzurum Kongresi kararlarını uygulamak ve daha geniş bir kongre yapmak üzere 29 Ağustos 1919'da Erzurum'dan Sivas'a hareket etmiştir. 2 Eylül 1919'da Sivas'a varan Mustafa Kemal Paşa, Vali Reşit Paşa, Kolordu Kumandanı Selahattin Bey ile asker, öğrenci, sivil halk tarafından coşkuyla karşılanmıştır. Ardından Mustafa Kemal Paşa ile arkadaşları kongre binası olarak kullanılacak Mekteb-i Sultanî’ye geçmişlerdir ${ }^{15}$.

Sivas Kongresi 4-11 Eylül 1919 tarihleri arasında toplanmıştır. Mustafa Kemal Paşa, ilk gün bir açılış konuşması yapmıştır. Tam İstiklal yerine Mandacı, taraftarlarının ifadesiyle Müzaheretci ${ }^{16}$ politika takip edenlerin her ne kadar kongre sürecinde ağırlığı ciddi anlamda hissedilse de Sivas Kongresi'nin toplanma amacı ve Mustafa Kemal Paşa'nın Samsun'a çıkmasından itibaren takip ettiği yol, bu açılış konuşmasındaki kendi ifadelerinde açık bir şekilde ortadadır. Buna göre genel anlamda her milletin kendi kaderini tayin etme hakk1 şeklinde formüle edilen Wilson Prensipleri İlkeleri, bir başka ifade ile bu vaatler üzerine dayanılarak yapılan ve Osmanlı Devleti ile İtilaf Devletleri arasındaki silah birakma şartlarını belirleyen Mondros Mütarekesi ve sonraki süreç beklentileri karşılamamıştır. Zira Mondros Mütarekesi sonrası adaletli bir sulh uygulaması ortaya konulmadığı gibi, her geçen gün kötüye giden bir süreç başlamıştı. Nitekim İtilaf Güçlerinin Mütareke ahkâmına aykırı işgalleri ve gayrimüslim unsurların, Yunanistan'ın Osmanlı coğrafyasını parçalama hususunda takındıkları kabul edilemez ve hukuk dışı hareketler giderek artmaktaydı. Mondros Mütarekesi hükümleri Osmanlı Devleti aleyhine kötüye kullanılmaktaydı. Ancak Mustafa Kemal Paşa'nın kongre açılış konuşmasında vurguladığı bir başka hususun üzerinde önemle durulmalıdır. Bu önemli husus, Osmanlı Devleti’nin “kalpgâhı” İstanbul'un İşgal Güçlerinin kontrolü altına girmesiydi. Bu işgale "hükümet-i merkeziye" tarihte bir örneği görülmemiş bir şekilde zayıflık göstererek "tahammül” ederken, millet "mevcudiyetini ispat ve fiili tecavüzlere karşı namus ve istiklalini bilfiil müdafaa" etmişti ${ }^{17}$. Dolayısıyla İstanbul acizlik içinde, ülkesi lehine kararlar veremez bir hale gelmiş, millet ise "çare-i halâsı" kendisinde görmüştür.

15 Sivas Vilayetinden Dâhiliye Nezaretine gönderilen 3 Eylül 1919 tarihli şifre, BOA, DH.ŞFR, 645/63-1, lef 1; Sivas Valisi Reşit Paşa'nın Hatıraları, İstanbul t.y., s. 135-136; Mazhar Müfit Kansu, a.g.e., I, s. 193-207.

16 Manda kavramı yerine Müzaheret ve benzeri ibareler için bkz. Fatih M. Sancaktar, "Türkçe İstanbul Gazetesinin Osmanlı Devleti Üzerinde kurulacak Bir Himaye İdaresine Örnek Bulma Çabası”, İlkadım 'dan Cumhuriyet'e Milli Mücadele, ed. Osman Köse, İstanbul 2008, s. 184.

17 Mustafa Kemal Atatürk, a.g.e., III (Vesikalar), s. 945-947; İşgal Güçlerinin ve Gayrimüslimlerin Osmanlı Devleti aleyhine faaliyetleri ve Mondros Mütarekesine aykırı uygulamalar için bkz. Abdurrahman Bozkurt, İtilaf Devletlerinin İstanbul'da İşgal Yönetimi, ATAM, Ankara 2014, s. 170-260, 281-376; Fatih M. Sancaktar, “Mondros Mütarekesi'nin 20. Maddesi ve İtilaf Güçlerinin Çatalca ve İstanbul Boğazı'ndaki Osmanlı Askeri Mühimmatını İmha veya Satma Girişimlerine Osmanlı Devleti’nin Engel Olma Çabası”, Imparatorluklar Çağına Veda, ed. Süleyman Beyoğlu, Bülent Bakar, Okan Yeşilot, Ötüken, İstanbul 2018, s. 255-283; Selçuk Ural, “İngiltere'nin Mondros Mütarekesi’nin 20. Maddesi'ne Aykırı Uygulamaları”, Ankara Üniversitesi Türk Inkılap Tarihi Enstitüsü Atatürk Yolu Dergisi, sayı 44, Ankara 2009, s. 713-742. 
Bu yüzden Sivas Kongresi kararlarında, İtilaf Güçlerine ve yereldeki destekçilerine karşı müdafaa ve mukavemet, gerekirse işgallere karşılık verilmesi ve direnme açık bir şekilde görülmektedir. Yine Sivas Kongresi'nde İstanbul Hükümeti'nin ülke aleyhine takındığı politikaların kabul görmeyeceği, vatan ve millet lehine kararlar alacak, bütün ülkeyi kuşatacak ve direnişçi milli unsurları bir araya toplayacak genel bir organizasyonun, teşkilatın kurulması ve mücadele ilkesinin belirlenmesi ve uygulanması yönünde kararlar alınmıştır. Bu yapılar Anadolu ve Rumeli Müdafaa-1 Hukuk Cemiyeti ve bir icra organı olana Heyet-i Temsiliye idi $^{18}$. Bu noktalardan hareketle Sivas Kongresi kararları, Milli Mücadele'nin bir programı ve uygulanma şeklini belirleyen bir temel metin olmasının yanı sıra, Anadolu Hareketi'nin kabul görmesinde, iktidar merkezi haline gelmesinde ve Kurtuluş Savaşı'nın başarısında önemli bir adımdı.

Sivas Kongresi'nde Manda, Ittihatçılık, kongre delegelerine ait Yemin Metni, Beyanname gibi oldukça önemli konular gündemi gelmiştir. Kongrede İsmail Fazıl Paşa, Bekir Sami, Vasıf ve özellikle kaleme alan İsmail Hami Beyler tarafından bir muhtıra şeklinde hazırlanan Manda fikri uzun süren tartışmaların ardından kabul görmemiştir. Mustafa Kemal Paşa, Rauf Bey gibi birçok delege, kimi siyasilerin Amerikalılarla yaptıkları görüşmelerin resmi bir hüviyet taşımadığı vurgusunu özellikle yapmışlardır. Hoca Raif Efendi, Refet Bey, Ahmet Nuri Bey gibi şahsiyetler ise 'Manda yönetiminin' “istiklali” korumanın önünde ciddi bir engel oluşturacağını, direniş için yola çıkan Milli Harekete zarar vereceğini vurgulamışlardır19 ${ }^{19}$.

Diğer taraftan Sivas Kongresi ve Anadolu Hareketi'nin bir İttihatçı girişim olduğuna dair iddialar, İstanbul kaynaklı bir şekilde yayılmıştır. Bunun üzerine delegeler kongrenin fırkalar üstü bir oluşum olduğunun üzerinde durmuşlardır. Bu noktadan hareketle delegeler İttihatçılık ve herhangi firka fikriyatı takip edilmeyeceğini açık bir şekilde dile getirmişlerdir. Kongredeki yemin metni, bu tartışmalar dikkate alınarak hazırlanmıştır ${ }^{20}$. 11 Eylül 1919'da 7. ve 8. maddeleri Erzurum Kongresi kararlarıyla “aynen” olan ve Sivas Kongresindeki tartışmalarının sonucunu gösteren "Umumi Kongre Beyannamesidir" adı altında 10 maddelik bir bildiri yayınlanmıştır. Kongre kararlarını takip edecek bir icra organı olan ve başkanlığını Mustafa Kemal Paşa'nın yaptı̆̆ı yeni bir Heyet-i Temsiliye, Erzurum Kongresi'ne göre genişletilerek oluşturulmuştur. Milli hareketin bir elden ve daha güçlü bir şekilde sürdürülebilmesi için bütün Müdafaa-i Hukuk ve direniş yapıları Anadolu ve Rumeli Müdafaa-i Hukuk Cemiyeti altında toplanmıştır ${ }^{21}$.

18 Sivas Kongresi Belgeleri, haz. Recep Toparlı, Sivas Vilayet Kitaplı̆̆ı, Sivas 2015, s. 12-20.

19 İsmail Fazıl Paşa, Bekir Sami Bey, İsmail Hami Bey tarafından hazırlanan Manda önerisine dair geniş metin, 8 Eylül 1919 tarihli Sivas Kongresi’nin 4. Oturumunun gündemini uzun süre meşgul etmiştir.

20 Sivas Kongresi Tutanaklarl, s. 56-68.

21 Milli Egemenlik Belgeleri, s. 26-29. 


\section{B. Sivas Kongresi Delegeleri ve Temsil}

\section{Sivas Kongresi'ne Katılan Delegeler}

Yukarıda ifade edildiği üzere Erzurum'dan hareket eden Mustafa Kemal Paşa ve Erzurum Heyet-i Temsiliyesi, halk, Vali ve Kolordu Kumandanının bulunduğu bir kalabalık tarafından karşılanmıştı. Sivas'ta kongre için bazı ön hazırlıklar yapılmıştı²2. 4 Eylül'de Mustafa Kemal Paşa'nın açılış konuşmasıyla başlayan ilk oturumda kongre başkanı ve başkanlık divanı oluşturulmuştur ${ }^{23}$. Kongrenin ilk oturumunda bazı çalışma grupları kurulmasına karar verilmiştir. Evvela Sivas Kongresi’ne katılan delegelerin "murahhaslık vesikalarını" kontrol etmekle görevli bir Tedkik-i Vesaik Encümeni oluşturulmuştur. Bu encümen Mustafa Kemal Paşa, Rauf Bey ve Raif Efendi olmak üzere üç kişiden müteşekkildi ${ }^{24}$. Ancak bu komisyonun faaliyetine ve belgelerde delegelere dair tutanağa ve bütüncül bir çizelgeye rastlanılamamıştır ${ }^{25}$.

Dolayısıyla Sivas Kongresi üyeleri ve temsil bölgeleri ile ilgili resmi hüviyet taşıyan bir evrak ve belgeden şimdilik bahsetmek mümkün olamamaktadır. Bu yüzden bu araştırmanın ortaya çıkardığı sonuç, temelde tutanak ve belgelerin sunmuş olduğu dağınık verilerin bir araya getirilmesiyle sınırlıdır. Bu noktada çalışma, kongreye katılmış veya bölgelerinden seçilmiş olduğu halde, isimleri tutanak ve belgelere yansımayan delegelerin de bulunabileceğini ihtimal dışı tutmamaktadır. Nitekim tutanaklar ve belgeler dikkatlice incelendiğinde tespit edilenden daha fazla delegenin olabileceğini düşündüren ibarelere de rastlanmaktadır. Kongre genel kuruluna sunulan takrirlerde, önergelerde temsil ettiği şehri gözükmesine rağmen isim yazılmayan"26, "ve daha sair imzalar"27, "bu dahi”28 gibi ibareler görülmektedir. Bu durum katılımcı sayısını tespitte zorluk çıkarmakta veya tespit ettiğimiz

22 İsmail Fazıl Paşa Heyeti-i Temsiliye Sivas'a gelmeden önce bir hazırlık komisyonu oluşturduklarını ve çalışmalara başladıklarını ifade etmektedir. Sivas Kongresi Tutanakları, s. 48. Sivas Kongresi'nin toplanmasında, delegelerin yerleştirilmesinde, kongre binasının ve salonunun hazırlanmasında 3. Kolordu Kumandanı Selahattin Bey ile Vali Reşit Paşa'nın önemli katkıları olmuştur. Ali Fuat Cebesoy, Milli Mücadele Hatıralarl, Temel Y., İstanbul 2000, s. 190-191.

23 Sivas Kongresi Divan Heyeti şu şekilde oluşmuştu: Başkan Mustafa Kemal Paşa, Başkan Yardımcıları Rauf Bey ve Bekir Sami Bey, kâtipler ise İsmail Hami Bey ile Mehmet Şükri Bey. Bekir Sami Bey’in ikinci başkan yardımcılığından çekilmesi üzerine oylamada en çok üçüncü oy alan İsmail Fazıl Paşa getirilmiştir. Sivas Kongresi Tutanaklarl, s. 1-2.

24 Sivas Kongresi Tutanaklarl, s. 13-14.

25 Ankara Vilayetinden İstanbul'a gönderilen bir yazıda Sivas’ta toplanan "Teşkilat-1 Milliye Kongresinin" başkanlığına Mustafa Kemal Paşa'nın seçildiği ve 80 delegesinin bulunduğu ifade edilmiştir. Kongrenin toplanma amacı, Mondros Mütarekesi’nden itibaren menfaati sağlanamayan "milletin efkârına müracaat ve maddi-manevi müzaheretinin istihsali” idi. Ankara Vilayetinden Dâhiliye Nezaretine gönderilen 7 Eylül 1919 tarihli şifre, BOA, DH.KMS, 53-3/12, lef 3-4. İsmail Fazıl Paşa, "Vilayat-1 Şarkiye” delegeleri Sivas’a gelmeden önce "takriben 25 kişi” olduklarını ifade etmektedir. Sivas Kongresi Tutanaklarl, s. 48.

26 Karesi ibaresinin altında herhangi bir delege ismi bulunmamaktadır. Sivas Kongresi Tutanaklarl, s. 133.

27 Sivas Kongresi Tutanaklarl, s. 54.

28 "Bu dahi" ifadesinin altında herhangi bir delege ismi bulunmamaktadır. Toparl1, Sivas Kongresi Tutanaklarl ve Belgeleri, s. 502. 
isimlerden farklı kişilerin de katıldığı izlenimini ortaya çıkarmaktadır. Diğer taraftan kongre tutanaklarının da sağlıklı tutulmadığı anlaşılmaktadır. Bu meyanda Kongre başkanının seçimindeki oylamaya dair delegeler ve divan heyeti arasında yaşananlar gösterilebilir. Divan Kâtibi olan İsmail Hami Bey, kongre zabıtlarını kaleme alan kâtiplerin tutanakları "gayr-1 muntazam ve noksan" tuttuklarını ifade etmiştir ${ }^{29}$.

Bununla birlikte kaynak olarak kullandığımız orijinal tutanak ve belgelerdeki isimler, delegelerin kesin ve daha doğru tespitine imkân sağlamıştır. Bu meyanda Sivas Kongresi tutanaklarının, isimleri ve bazen temsil yerlerinin yazılı bir şeklinde tutulması, adeta Osmanlı Meclis-i Mebusan Zabıt Ceridelerini andırmaktadır ${ }^{30}$. Ayrıca tutanaklarda benzer isimlerin karışmasını önlemek için bazı hususlara dikkat edildiği anlaşılmaktadır. Nitekim Sivas Kongresi'nde Mehmet Şükri Bey adında iki kişi bulunmaktadır. Bu iki kişinin isminin yanına temsil ettiği şehirlerin adları yazılarak karışıklık önlenmeye çalışılmıştır. Böylece delegelerin tespitinde kolaylık sağlanmıştır ${ }^{31}$. Yine ikinci adları Hami olan delegelerin yazımında, bu farklılıkların da dikkate alındığı görülmektedir. Bu iki delege İsmail Hami ve Halid Hami Beyler idi. Tutanaklarda Halid Hami Bey, İsmail Hami Bey'den ayırt edilebilecek bir surette, Halid Bey veya Halid Hami Bey şeklinde kaydedilmiştir. Özellikle Kongreye verilen önergelerde delegelerin isimlerini ve şehirlerini tespit etmek ve farklılıkları görmek daha fazla mümkün olabilmektedir ${ }^{32}$.

Kongre tutanak ve belgelerinin incelenmesiyle ve yukarıdaki kriterler dikkate alınarak yeni bir delege tablosu ortaya çıkarılmaya çalışılmıştır. İlk olarak bazı hatıralar ve telif eserler incelenmiştir. Bu çalışmalardan bir delege tablosu oluşturulmuştur. Hatıraları kaleme alanlar Sivas Kongresi esnasında Sivas'ta bulunan ve delegelik veya askeri ve sivil idari görevlerde bulunanlardır. Telif eserler ise bugüne kadar Sivas Kongresi delegelerine dair çeşitli istatistik bilgileri veren çalışmalardır. Bu çalışmalarda elde edilen isimler, aile adı/lakabı ve unvanlar birlikte listelenmiştir. Bu noktada bazı delegelerin aile adları arasında birtakım farklılıkların olduğu görülmektedir. Bu durum bazı delegelerin tespitinde zorluk çıkarmaktadır. Ancak farklılıkların bazen yazım hatasından da kaynaklandığı anlaşılmaktadır.

29 Sivas Kongresi’nde Kongre Başkanı seçiminde kaç oy kullanıldığı ve seçildiğine dair zabıtlarda kayıt yoktur. Bu yüzden 5 Eylül 1919 tarihli oturumda, delegeler konunun açıklanmasını istemişlerdir. Ancak kâtipler tutanakları "gayr-1 muntazam ve noksan" kaydetmelerinden dolayı oylama sonuçları belli değildir. Kesin sayı belli olmamakla birlikte delegeler "ittifak-1 ara" ile kongre başkanının seçildiği noktasındaki yaklaşımı benimsemişlerdir. Sivas Kongresi Tutanakları, s. 31-32.

30 Kongre müzakerelerinin bir yasama meclisi faaliyeti şeklinde devam etmesi karşısında İsmail Hami Bey, "fazla zaman kaybediyoruz. Biz Mebusan usulünü takip ediyoruz! Fakat zaman naziktir; bu işe tahammülü yoktur...” diyecektir. Sivas Kongresi Tutanakları, s. 36.

31 Mehmed Şükri Bey (Denizli) ve Mehmed Şükri Bey (Karahisar) için bkz. Sivas Kongresi Tutanaklarl, s. 37, 47.

32 İsmail Hami Bey ve Halid Hami Bey için bkz. Sivas Kongresi Tutanakları, s. 2, 6, $14,54$. 
Öncelikle 5 hatıra ve 3 telif eser dikkate alındığında aşağıdaki tablo (Tablo 1) ortaya çıkmaktadır. Delege isimleri bu çalışmalarda geçtiği şeklinde alınmıştır. Bu tabloya göre delege sayısı en fazla 51 kişi olarak gözükmektedir. Bu çalışmalarda ilk 24 delegeden sonra bir ortak kanaat bulunmamaktadır. İlk 24'ten sonraki 13 delege, bu çalışmalarda 1 ila 4 eksikle gözükmektedir. 35 . delegeden sonra çalışmaların ortak fikirde buluşma oranları ciddi bir şekilde düşmektedir. Tablo 1'deki hatıra ve telif eserler üzerinden ve karş1laştırarak hareket edildiğinde Sivas Kongresi'ne katılan delegelerin tam sayısını tespit etmenin oldukça zor olduğu anlaşılmaktadır.

\begin{tabular}{|c|c|c|c|c|c|c|c|c|c|}
\hline & 5 Hatıra ve 3 Telif Es & e Al & $\begin{array}{l}\text { lo } 1 \\
\text { rak }\end{array}$ & zzorl & an I & gele & Dai & blo & \\
\hline 窄 & 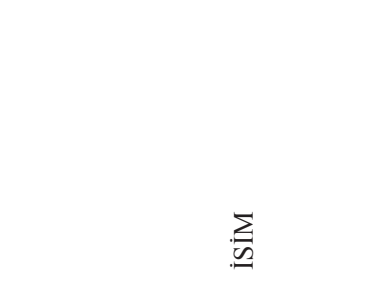 & 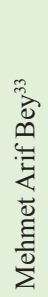 & 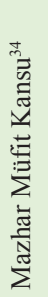 & 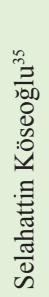 & 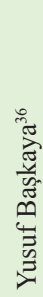 & 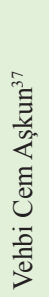 & 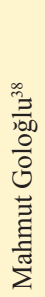 & 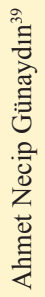 & 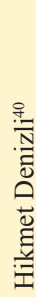 \\
\hline 1 & Mustafa Kemal Paşa & $\mathrm{X}$ & $\mathrm{X}$ & $\mathrm{X}$ & $\mathrm{X}$ & $\mathrm{X}$ & $\mathrm{X}$ & $\mathrm{X}$ & $\mathrm{X}$ \\
\hline 2 & Rauf Bey & $\mathrm{X}$ & $\mathrm{X}$ & $\mathrm{X}$ & $\mathrm{X}$ & $\mathrm{X}$ & $\mathrm{X}$ & $\mathrm{X}$ & $\mathrm{X}$ \\
\hline 3 & Bekir Sami Bey & $\mathrm{X}$ & $\mathrm{X}$ & $\mathrm{X}$ & $\mathrm{X}$ & $\mathrm{X}$ & $\mathrm{X}$ & $\mathrm{X}$ & $\mathrm{X}$ \\
\hline 4 & Emir İsmail Hami Bey & $\mathrm{X}$ & $\mathrm{X}$ & $\mathrm{X}$ & $\mathrm{X}$ & $\mathrm{X}$ & $\mathrm{X}$ & $\mathrm{X}$ & $\mathrm{X}$ \\
\hline 5 & Koçzade Mehmed Şükrî Bey & $\mathrm{X}$ & $\mathrm{X}$ & $\mathrm{X}$ & $\mathrm{X}$ & $\mathrm{X}$ & $\mathrm{X}$ & $\mathrm{X}$ & $\mathrm{X}$ \\
\hline 6 & İsmail Fazıl Paşa & $\mathrm{X}$ & $\mathrm{X}$ & $\mathrm{X}$ & $\mathrm{X}$ & $X$ & $\mathrm{X}$ & $\mathrm{X}$ & $\mathrm{X}$ \\
\hline 7 & Ahmed Nuri Bey & $\mathrm{X}$ & $\mathrm{X}$ & $\mathrm{X}$ & $\mathrm{X}$ & $\mathrm{X}$ & $\mathrm{X}$ & $\mathrm{X}$ & $\mathrm{X}$ \\
\hline 8 & Hoca Raif Efendi & $\mathrm{X}$ & $X$ & $\mathrm{X}$ & $\mathrm{X}$ & $X$ & $\mathrm{X}$ & $\mathrm{X}$ & $\mathrm{X}$ \\
\hline 9 & Hüsrev Sami Bey & $\mathrm{X}$ & $\mathrm{X}$ & $\mathrm{X}$ & $\mathrm{X}$ & $\mathrm{X}$ & $\mathrm{X}$ & $\mathrm{X}$ & $\mathrm{X}$ \\
\hline 10 & Siyahizade Halil İbrahim Efendi & $\mathrm{X}$ & $\mathrm{X}$ & $\mathrm{X}$ & $\mathrm{X}$ & $\mathrm{X}$ & $\mathrm{X}$ & $\mathrm{X}$ & $\mathrm{X}$ \\
\hline 11 & Bayraktarzade Hüseyin Bey & $\mathrm{X}$ & $\mathrm{X}$ & $\mathrm{X}$ & $\mathrm{X}$ & $\mathrm{X}$ & $\mathrm{X}$ & $\mathrm{X}$ & $\mathrm{X}$ \\
\hline 12 & Macid Bey & $\mathrm{X}$ & $\mathrm{X}$ & $\mathrm{X}$ & $\mathrm{X}$ & $\mathrm{X}$ & $\mathrm{X}$ & $\mathrm{X}$ & $\mathrm{X}$ \\
\hline 13 & Miralay Vasıf Bey & $\mathrm{X}$ & $\mathrm{X}$ & $\mathrm{X}$ & $\mathrm{X}$ & $\mathrm{X}$ & $\mathrm{X}$ & $\mathrm{X}$ & $\mathrm{X}$ \\
\hline 14 & Mazhar Müfid Bey & $\mathrm{X}$ & $\mathrm{X}$ & $\mathrm{X}$ & $\mathrm{X}$ & $\mathrm{X}$ & $\mathrm{X}$ & $\mathrm{X}$ & $\mathrm{X}$ \\
\hline
\end{tabular}

33 Miralay Mehmet Arif Bey, Anadolu Ihtilali -Milli Mücadele Anılarl- (1919-1923), haz. Bülent Demirbaş, Arba, İstanbul 1987, s. 30-31.

34 Kansu, a.g.e., I, s. 251-252.

35 İkinci Grup'un Kurucularından Salâhattin Kösoğlu'nun Milli Mücadele Hatıraları, haz. Ahmet Demirel, İletişim, İstanbul 2017, s. 152-153.

36 Yusuf Başağazade'nin listesi için Mahmut Goloğlu’nun eseri kullanılmıştır. Mahmut Goloğlu, Sivas Kongresi, Başnur Matbaası, Ankara 1969, s. 230-231.

37 Vehbi Cem Aşkun, Sivas Kongresi, İstanbul 1963, s. 148-149.

38 Goloğlu, Sivas Kongresi, s. 68-74.

39 Ahmet Necip Günaydın, Milli Mücadelede Sivas-108 Gün (2 Eylül-18 Aralık 1919), 3. Bask1, Sivas Vilayet Kitaplığı, Sivas 2019, s. 89-96. Günaydın’ın kaleme aldığı bu eser, çalışmamızda kongre delegelerinin sayısına dair tespitlerimize en yakın araştırmadır.

40 Hikmet Denizli, Sivas Kongresi Delegeleri ve Heyet-i Temsiliye Üyeleri, Kültür Bakanlı̆̆ı Y., Ankara 1996, s. 66-73. 


\begin{tabular}{|c|c|c|c|c|c|c|c|c|c|}
\hline 15 & Başağazade/Büyükağa Yusuf Bey & $\mathrm{X}$ & $\mathrm{X}$ & $\mathrm{X}$ & $\mathrm{X}$ & $\mathrm{X}$ & $\mathrm{X}$ & $\mathrm{X}$ & $\mathrm{X}$ \\
\hline 16 & Boşnakzade Süleyman Bey & $\mathrm{X}$ & $\mathrm{X}$ & $\mathrm{X}$ & $\mathrm{X}$ & $\mathrm{X}$ & $\mathrm{X}$ & $\mathrm{X}$ & $\mathrm{X}$ \\
\hline 17 & Halid Hami Bey & $\mathrm{X}$ & $\mathrm{X}$ & $\mathrm{X}$ & $\mathrm{X}$ & $\mathrm{X}$ & $\mathrm{X}$ & $\mathrm{X}$ & $\mathrm{X}$ \\
\hline 18 & Hikmet Bey & $\mathrm{X}$ & $\mathrm{X}$ & $\mathrm{X}$ & $\mathrm{X}$ & $\mathrm{X}$ & $\mathrm{X}$ & $\mathrm{X}$ & $\mathrm{X}$ \\
\hline 19 & İbrahim Süreyye Bey & $\mathrm{X}$ & $\mathrm{X}$ & $\mathrm{X}$ & $\mathrm{X}$ & $\mathrm{X}$ & $\mathrm{X}$ & $\mathrm{X}$ & $\mathrm{X}$ \\
\hline 20 & Osman Nuri Bey & $\mathrm{X}$ & $\mathrm{X}$ & $\mathrm{X}$ & $\mathrm{X}$ & $\mathrm{X}$ & $\mathrm{X}$ & $\mathrm{X}$ & $\mathrm{X}$ \\
\hline 21 & Ratibzade Mustafa Efendi & $\mathrm{X}$ & $\mathrm{X}$ & $\mathrm{X}$ & $\mathrm{X}$ & $\mathrm{X}$ & $\mathrm{X}$ & $\mathrm{X}$ & $\mathrm{X}$ \\
\hline 22 & Sami Zeki Bey & $\mathrm{X}$ & $\mathrm{X}$ & $\mathrm{X}$ & $\mathrm{X}$ & $\mathrm{X}$ & $\mathrm{X}$ & $\mathrm{X}$ & $\mathrm{X}$ \\
\hline 23 & Mehmet Tevfik Bey & $\mathrm{X}$ & $\mathrm{X}$ & $\mathrm{X}$ & $\mathrm{X}$ & $\mathrm{X}$ & $\mathrm{X}$ & $\mathrm{X}$ & $\mathrm{X}$ \\
\hline 24 & Șeyh Fevzi Efendi & $\mathrm{X}$ & $\mathrm{X}$ & $\mathrm{X}$ & $\mathrm{X}$ & $\mathrm{X}$ & $\mathrm{X}$ & $\mathrm{X}$ & $\mathrm{X}$ \\
\hline 25 & Delâlzade Hacı Osman Efendi & $\mathrm{X}$ & $\mathrm{X}$ & - & $\mathrm{X}$ & $\mathrm{X}$ & $\mathrm{X}$ & $\bar{X}$ & $\mathrm{X}$ \\
\hline 26 & Abdurrahman Dursun/ Tosun Bey & - & $\mathrm{X}$ & $\mathrm{X}$ & $\mathrm{X}$ & $\mathrm{X}$ & $\mathrm{X}$ & $\mathrm{X}$ & $\mathrm{X}$ \\
\hline 27 & Kesrizade Salih Sıdkî Bey & $\mathrm{X}$ & $\mathrm{X}$ & - & $\mathrm{X}$ & $\mathrm{X}$ & $\mathrm{X}$ & $\mathrm{X}$ & $\mathrm{X}$ \\
\hline 28 & Küçükağazade Necip Ali Bey & - & $\mathrm{X}$ & $\mathrm{X}$ & $\mathrm{X}$ & $\mathrm{X}$ & $\mathrm{X}$ & $\mathrm{X}$ & $\mathrm{X}$ \\
\hline 29 & Refet Bey & - & $\mathrm{X}$ & $\mathrm{X}$ & $\mathrm{X}$ & $\mathrm{X}$ & $\mathrm{X}$ & $\mathrm{X}$ & $\mathrm{X}$ \\
\hline 30 & Ömer Mümtaz Bey & $\mathrm{X}$ & $\mathrm{X}$ & $\mathrm{X}$ & - & $\mathrm{X}$ & $\mathrm{X}$ & $\mathrm{X}$ & $\mathrm{X}$ \\
\hline 31 & Hakkı Behiç Bey & $\mathrm{X}$ & $\mathrm{X}$ & $\mathrm{X}$ & - & $\mathrm{X}$ & $\mathrm{X}$ & $\mathrm{X}$ & - \\
\hline 32 & Yusuf Bahri Bey & - & - & $\mathrm{X}$ & $\mathrm{X}$ & $\mathrm{X}$ & $\mathrm{X}$ & $\mathrm{X}$ & $\mathrm{X}$ \\
\hline 33 & Kalaçzade Ahmet Hilmi & - & - & $\mathrm{X}$ & - & $\mathrm{X}$ & $\mathrm{X}$ & $\mathrm{X}$ & $\mathrm{X}$ \\
\hline 34 & Katibzade Nuh Naci & - & - & $\mathrm{X}$ & - & $\mathrm{X}$ & $\mathrm{X}$ & $\mathrm{X}$ & $\mathrm{X}$ \\
\hline 35 & $\begin{array}{l}\text { Dalamanlı/Dalhanlı Ağazade Mehmed } \\
\text { Şükri }\end{array}$ & $\mathrm{X}$ & - & - & - & - & $\mathrm{X}$ & $\mathrm{X}$ & $\mathrm{X}$ \\
\hline 36 & İmamzade Ömer Mümtaz Bey & - & - & $\mathrm{X}$ & - & - & - & $\mathrm{X}$ & $\mathrm{X}$ \\
\hline 37 & Tatlızade Nuri Efendi & - & - & - & - & - & $\mathrm{X}$ & $\mathrm{X}$ & $\mathrm{X}$ \\
\hline 38 & Rüstem Bey & - & - & $\overline{\mathrm{X}}$ & 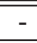 & $-\overline{-}$ & 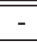 & 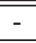 & $\overline{\mathrm{X}}$ \\
\hline 39 & Necati Bey & - & - & $\mathrm{X}$ & - & - & - & - & - \\
\hline 40 & Raif Bey & - & - & - & $\mathrm{X}$ & - & - & - & - \\
\hline 41 & Hasan Efendi & - & - & - & - & - & - & $\mathrm{X}$ & - \\
\hline 42 & İhsan Hamit & - & - & - & - & - & - & $\mathrm{X}$ & $\mathrm{X}$ \\
\hline 43 & Rauf Bey & $\mathrm{X}$ & - & - & - & - & - & - & - \\
\hline 44 & Selahattin Bey (3. Kolordu Komutanı) & - & - & $\mathrm{X}$ & - & - & - & - & - \\
\hline 45 & İzzet Bey & - & - & - & - & - & - & - & $\mathrm{X}$ \\
\hline 46 & Servet Bey & - & - & - & - & - & - & - & $\mathrm{X}$ \\
\hline 47 & Yusuf Bey & - & - & - & - & - & - & - & $\mathrm{X}$ \\
\hline 48 & Sadullah Ef. & - & - & - & - & - & - & - & $\mathrm{X}$ \\
\hline 49 & Hacı Musa Ef. & - & - & - & - & - & - & - & $\mathrm{X}$ \\
\hline 50 & Bekir Bey & - & - & $\mathrm{X}$ & - & - & $\mathrm{X}$ & $\mathrm{X}$ & $\mathrm{X}$ \\
\hline 51 & Asaf Bey & - & - & - & - & - & $\mathrm{X}$ & $\mathrm{X}$ & $\mathrm{X}$ \\
\hline
\end{tabular}

Diğertaraftan tutanaklarve belgeleri esas alarak ve birtakım kriterlerüzerinden hazırladığımız Tablo 2 bazı farklılıkları ortaya çıkarmaktadır. Bu tabloda Sivas Kongresi tutanaklar ve belgelerinde konuşan, takrir veren ve adı geçenlerin isimleri tespit ve kaydedilmiştir. Tespit edilen bu isimlerin, konuşma yaptığı, takrir verdiği ve adı geçtiği oturumlar tespit edilmeye çalışılmıştır. Ayrıca delege isimleri tutanak ve belgelerde geçtiği şekilde kaydedilmiştir. Burada delege isim ve sayısının tespitinde, tutanaklarda adeta Meclis-i Mebusan Zabit Ceridelerindeki 
gibi şehir adlarının belirtilmesi, bir kolaylık sağlamıştır. Nitekim bu husus, aynı adı taşıyan Denizli ve Afyonkarahisar temsilcileri Mehmed Şükri Beyleri ayırma imkânı sağlamıştır.

Bunun yanı sıra kongre oturumlarındaki gündemler verilerek delegelerin faaliyetlerinin ortaya çıkarılması amaçlanmıştır. Doğal olarak delegelerin böylesine önemli bir kongre sırasındaki faaliyetleri ifade ettiğimiz kriterler ve gündemler çerçevesinde tam olarak gösterilemez. Nitekim hem kongreye dair bilgi, belge ve tutanaklardaki sorunlar göz ardı edilemez hem de delegelerin kongre esnasındaki faaliyetlerinin tümü kayıt altına alınamaz. Bununla birlikte gündem ve delege ilişkisinin ortaya konulması, kongrenin genel bir değerlendirmesi için fikir verecektir.

Tablo 2 ve tutanaklar incelendiğinde Mustafa Kemal Paşa ve İsmail Hami Bey’in sıkça konuştuğu görülecektir. Ancak Mustafa Kemal Paşa'nın kongre başkanı ve İ. Hami Bey’in kâtip olarak gündem konusu üzerinde fikir beyan etmelerinin yanı sıra bazen yönetmek, sunulan takrirleri, gündemleri okumak için söz aldıkları dikkate alınmalıdır. Diğer taraftan kongrede söz alan delegeler, ilk oturumdan itibaren bellidir ve sıkça uzun konuşmalar yapmışlardır. Bu durumun tersine kongreye sunulan takrirlerde imzaları olan delegelerin önemli bir kısmı hiç konuşmamışlar veya çok az konuşmuşlardır. Bununla birlikte kongreye verilen takrirler, delege isimleri ve temsil ettikleri şehirleri tespit etmeye imkân vermiştir.

Tablo 2'deki ilk 35 delegeyi, kongre tutanakları ve belgelerinde kesinlikle tespit etmek mümkündür. Ancak hatıra ve telif eserler üzerine kurulu Tablo 1'deki ilk 35 delegeden farklılıklar göstermektedir. Hatta 35 ve daha fazla delege gösteren eserlerden ayrıldığı bazı noktalar olduğu ifade edilebilir. Bunları şu şekilde sıralamak mümkündür:

3. Kolordu Komutanı Selahattin Bey ile Hasan Efendi adlı bir şahıs tutanaklarda konuşma yapanlar arasında bulunmaktadır. Selahattin Bey, sadece kendi hatıratında delege olarak gösterilmektedir. Selahattin Bey'in hatıratına göre bazı ordu komutanları da kongre "azası” olarak sayılmışt ${ }^{41}$. Kanaatimizce Selahattin Bey, Sivas Kongresi delegesi olarak kabul edilmelidir. Zira kongre tutanak ve belgelerinde, belirlediğimiz konuşma veya adı geçme kriterine uymaktadır. Selahattin Bey, 6. Oturumda Sivas Kongresi adına padişaha gönderilecek yazıya dair gündemde, görüşlerini ve tekliflerini birden fazla söz alarak ifade etmiştir. Kongre delegelerince hiçbir itiraz veya yasaklamaya maruz kalmamıştır ${ }^{42}$. Oysaki kongredeki konuşmaları kayıt altına almakla görevli olan zabıt kâtibi Salahaddin Bey, delege olmadığı halde 5. Oturumda söz almak istemiştir. Delegeler, kendisine kongrede konuşmaya yetkili olmadığı uyarısını yapmışlardır ${ }^{43}$. Diğer

41 3. Kolordu Kumandanı Selahattin Bey’e göre, kendisi dâhil 15. Kolordu Kumandanı Kazım Karabekir, 20. Kolordu Kumandanı Ali Fuat Bey (Cebesoy), 13. Kolordu Kumandanı Cevdet Paşa Sivas Kongresi delegeleri arasında idi. Bunlar arasında Sivas merkezindeki 3. Kolordu kumandanı olarak kendisi toplantılara katılmakta ve diğerleri izinli sayılmaktaydı. Salâhattin Kösoğlu’nun Milli Mücadele Hatıraları, s. 153.

42 Sivas Kongresi Tutanaklarl, s. 121-125.

43 Sivas Kongresi Tutanaklarl, s. 116/86; Mehmet Arif Bey'e göre delege olmadıkları halde birçok kimse kongrede hazır bulunmaktayd. Mehmet Arif Bey, a.g.e., s. 31. 
taraftan Selahattin Bey'in delegeliğini izah edecek bir başka olay, yine kongre tutanaklarında karşımıza çıkmaktadır. Mustafa Kemal Paşa tarafından Refet Bey (Bele), Erzurum Heyet-i Temsiliyesi üyesi sıfatıyla kongre delegesi olarak tanıtılmıştır ${ }^{44} .4$ farklı oturumda uzun uzun konuşmalar yapan Refet Bey’in delegeliğine itiraz edilmemiştir. Hâlbuki Refet Bey, Erzurum'da Heyet-i Temsiliye üyesi olarak seçilmemiş, hatta kongre üyesi olmamıştır ${ }^{45}$.

Hasan Efendi, sadece birinci oturumda ve bir kez söz almıştır. Bu delege hakkında tutanak ve belgelerde başka bir bilgiye rastlanmamaktadır. Aynı oturumda birkaç kez konuşma yapan ve Osmanlı Türkçesi ile yazımları yakın olan Hüseyin adlı bir delege daha bulunmaktadır. Ancak bütün tutanak nüshalarında Hasan Efendi'yi, Hüseyin Bey şeklinde okumak mümkün olmadığı gibi, Hasan ismi Efendi ibaresiyle birlikte yazılmıştır ${ }^{46}$.

Hatıra ve telif eserlerde sıkça geçen Ömer Mümtaz Bey ismi karışıklığa neden olmaktadır. Zira Ankara ve Kayseri delegesi olarak iki Ömer Mümtaz Bey'den bahsedilmektedir. Sivas Kongresi'nde hiçbir oturuma katılmayan bu iki farklı kişiyi doğru tespit edenler olduğu gibi, Ömer Muhtar veya Mümtaz şeklinde, hatta tek bir kişi olarak kaydedildiği de görülmektedir ${ }^{47}$. Aslında bu karışıklığa belgelerde de sebep olacak yazımlara rastlanmaktadır. 6 Eylül 1919 tarihli 20. Kolordu Komutanı Ali Fuat Bey'in kongreye gönderdiği belgede Eski Mebus Ömer Muhtar Bey’in Mazhar Müfit Bey’le birlikte ikinci Ankara delegesi olarak seçildiği ve yola çıktığı belirtilmiştir ${ }^{48}$. Diğer taraftan her iki Ömer Mümtaz Bey de 1914-1918 Meclis-i Mebusan'ında Kayseri ve Ankara mebusları olarak bulunmuşlardır ${ }^{49}$. Ankara'yı temsilen Sivas'a giden Ömer Mümtaz Bey, oturumlara katılmadığı halde, Heyet-i Temsiliye üyeliğine seçilmiştir. İmamzade lakabıyla tanınan Ömer Mümtaz Bey, Kayseri’yi temsilen Kalaçzade Ahmet Hilmi Efendi, Katibzade Nuh Naci Efendi ile birlikte Sivas'a gelmiştir. Ancak Kayseri temsilcileri Sivas'a ulaştıklarında kongre tamamlanmışt1 ${ }^{50}$. Dolayısıyla Sivas Kongresi sonrasındaki faaliyetlere katılabilmişlerdir. Bir başka rastlanan isim, Tatlızade Nuri Efendi'dir. Fakat Nuri Efendi, Sivas’ta bulunmasına rağmen hastalığı nedeniyle oturumlara katılamamıştır. Bu yüzden tutanak ve belgelerde bu isim görünmemektedir ${ }^{51}$.

44 Sivas Kongresi Tutanaklarl, s. 50.

45 Kansu, s. 78-80, 112.

46 Hasan Efendi, Sivas'tan bazı kimselerin kongreye dinleyici olarak girmesi talebine dair oturum esnasında söz almıştır. "Biz cemiyet-i inkllabiyeyiz. Bit-tabi’kimse giremez. Yalnız kongrenin hitamında mukarreratımızı dinleyebilirler" şeklindeki ifadesiyle Sivas Kongresi'nin önem ve amacını vurgulamıştır. Sivas Kongresi Tutanaklarl, s. 28; Toparl, Sivas Kongresi Tutanaklarl ve Belgeleri, s. 57, 294, 401.

47 Kansu, a.g.e., s. 251, 284; Mehmet Arif Bey, a.g.e., s. 32; Goloğlu, Sivas Kongresi, s. 72-74; Salâhattin Kösoğlu’nun Milli Mücadele Hatıralart, s. 152-153; Aşkun, a.g.e., s. 148-149; Cebesoy, a.g.e., s. 186, 197-198.

48 Toparlı, Sivas Kongresi Tutanaklarl ve Belgeleri, s. 506-507. Ömer Mümtaz Bey şeklindeki yazımlar için bkz. Toparl, Sivas Kongresi Tutanaklarl ve Belgeleri, s. 266, 458-459, 500.

49 MM Zabıt Ceridesi, D. 3, İçtima Senesi 1, I, 1. Oturum (1 Kanun-1 Evvel 1914), s. 2, 4, 7-8; Sibel Yazıc1, Osmanlı Meclis-i Mebusanı ve Faaliyetleri (1914-1918), Afyon Kocatepe Üniversitesi, Yayınlanmamış Doktora Tezi, Afyonkarahisar 2018, s. 21.

50 Salâhattin Kösoğlu'nun Milli Mücadele Hatıraları, s. 153.

51 Goloğlu, Sivas Kongresi, s. 72. 


\begin{tabular}{|c|c|c|c|c|c|c|}
\hline \multicolumn{7}{|c|}{$\begin{array}{c}\text { Tablo } 2 \\
\text { Sivas Kongresi Tutanakları ve Belgeleri Dikkate Alınarak Hazırlanan Delegelere Dair Tablo }\end{array}$} \\
\hline \multirow[b]{2}{*}{ Say 1} & \multirow[b]{2}{*}{ İSİM } & \multicolumn{3}{|c|}{\begin{tabular}{|c|} 
Tutanaklarda/Belgelerde \\
\end{tabular}} & \multirow[b]{2}{*}{ 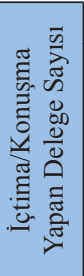 } & \multirow[b]{2}{*}{ Kongre Gündemi ${ }^{52}$} \\
\hline & & 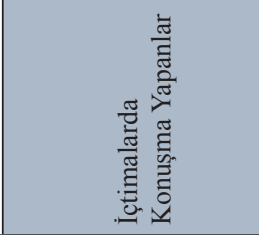 & 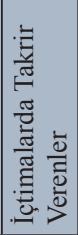 & 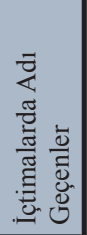 & & \\
\hline 1 & Mustafa Kemal Paşa & Bütün İçtimalar (1-8) & & & \multirow{4}{*}{$1 / 15$} & \multirow{4}{*}{ 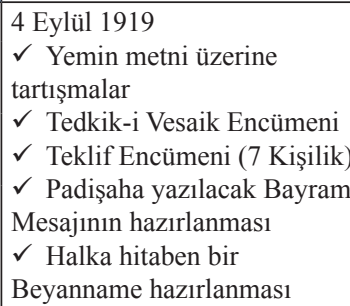 } \\
\hline 2 & Emir İsmail Hami Bey & Bütün İçtimalar (1-8) & 4 & & & \\
\hline 3 & Ferik İsmail Fazıl Paşa & Bütün İçtimalar (1-8) & 4 & & & \\
\hline 4 & Rauf Bey & $1,2,3,5,6,7,8$ & & & & \\
\hline 5 & $\begin{array}{l}\text { Mehmed Şükrî Bey } \\
\text { (Karahisar-1 Sahib) }\end{array}$ & $1,2,3,4,5,6,8$ & 3 & & \multirow[b]{5}{*}{$2 / 13$} & \multirow{5}{*}{$\begin{array}{l}5 \text { Eylül } 1919 \\
\checkmark \text { Yemin Metni ve yemin } \\
\text { edilmesi } \\
\checkmark \text { Padişaha yazılacak Bayram } \\
\text { Mesajının hazırlanması } \\
\checkmark \text { Halka hitaben bir } \\
\text { Beyanname hazırlanması } \\
\checkmark \text { Vasıf Bey’in Teklif } \\
\text { Encümenine girmesi } \\
\checkmark \text { Manda Konusunu içerin } \\
\text { Muhtıra } \\
\checkmark \text { Ve Erzurum Kongresi } \\
\text { Beyannamesinin Encümene } \\
\text { gönderilmesi }\end{array}$} \\
\hline 6 & Ahmed Nuri Bey & $1,2,3,4,5,6,8$ & 8 & & & \\
\hline 7 & Mazhar Müfid Bey & $2,3,4,5,6,7,8$ & 7,3 & & & \\
\hline 8 & Bekir Sami Bey & $1,2,4,5,6,8$ & 4,7 & & & \\
\hline 9 & Osman Nuri Bey & $1,4,5,6,7,8$ & 7,8 & & & \\
\hline 10 & Hoca Raif Efendi & $1,2,3,4,6,7$ & 7 & & \multirow[b]{4}{*}{$3 / 21$} & \multirow{4}{*}{$\begin{array}{l}7 \text { Eylül } 1919 \\
\checkmark \text { Kongreye gönderilen tebrik } \\
\text { telgraflarının okunması ve } \\
\text { cevap yazılması } \\
\checkmark \text { Erzurum Kongresi } \\
\text { Beyannamesi } \\
\checkmark \text { Sivas Belediyesine } \\
\text { Bayramlaşma için bir heyet } \\
\text { gönderilmesi }\end{array}$} \\
\hline 11 & Hüsrev Sami Bey & $1,2,3,4,6,8$ & & & & \\
\hline 12 & Refet Bey & $3,4,5,6$ & & & & \\
\hline 13 & Hüseyin Bey & $1,7,8$ & 3,8 & & & \\
\hline 14 & Macid Bey & $2,4,5$ & 8 & & \multirow{4}{*}{$4 / 13$} & \multirow{4}{*}{$\begin{array}{l}8 \text { Eylül } 1919 \\
\checkmark \text { Tebrik telgrafları ve cevap } \\
\text { yazılması } \\
\checkmark \text { Teklif Encümeninden gelen } \\
\text { Manda içerikli Muhtıranın } \\
\text { okunması, tartışmalar ve geri } \\
\text { çekilmesi }\end{array}$} \\
\hline 15 & $\begin{array}{l}\text { Mehmed Şükri } \\
\text { (Denizli) }\end{array}$ & $2,6,7$ & 3,8 & & & \\
\hline 16 & Halid Hami Bey & 1,5 & 3,8 & & & \\
\hline 17 & Halil İbrahim Efendi & 1,8 & 3 & & & \\
\hline
\end{tabular}

52 Sivas Kongresi’nin devam ettiği 4-11 Eylül 1919 tarihleri arasındaki zaman dilimi içinde, toplam 8 oturum yapılmıştır. Kurban Bayramının birinci gününe denk gelen 6 Eylül Cumartesi toplantı yapılmamış, 10 Eylül'de ise 2 oturum (6. ve 7. İçtimalar) birden gerçekleştirilmiştir. 


\begin{tabular}{|c|c|c|c|c|c|c|}
\hline 18 & Miralay Vasıf Bey & 2,4 & 3 & & \multirow[b]{5}{*}{$5 / 12$} & \multirow{5}{*}{$\begin{array}{l}9 \text { Eylül } 1919 \\
\checkmark \text { Erzurum Kongresi } \\
\text { Beyannamesi üzerine } \\
\text { görüşmeler } \\
\checkmark \text { Amerikan Kongresine bir } \\
\text { heyet gönderilmesi için davet } \\
\text { yapılması } \\
\checkmark \text { Tebrik telgrafları ve cevap } \\
\text { yazılması } \\
\checkmark \text { Ali Fuat Paşa'nın Batı } \\
\text { Anadolu Kuva-yı Milliye } \\
\text { Güçlerinin Başkomutanlığına } \\
\text { atanması } \\
\checkmark \text { Batı bölgelerde Sivas } \\
\text { Kongresi aleyhine yapılan } \\
\text { girişimler ve önlenmesine dair } \\
\text { tedbirler } \\
\checkmark \text { Mebus seçimlerinin en kısa } \\
\text { sürede yapılmasına dair çaba } \\
\text { sarf edilmesi }\end{array}$} \\
\hline 19 & İbrahim Süreyya Bey & 7 & 7,3 & & & \\
\hline 20 & Yusuf Bey & 7 & 3,8 & & & \\
\hline 21 & Hikmet Bey & 7 & 3 & & & \\
\hline 22 & Abdurrahman Tosun B. & 1 & & & & \\
\hline 23 & $\begin{array}{l}\text { 3. Kolordu Komutanı } \\
\text { Selahattin Bey }\end{array}$ & 6 & & & \multirow{4}{*}{$6 / 14$} & \multirow{4}{*}{$\begin{array}{l}10 \text { Eylül } 1919 \\
\checkmark \text { Padişaha yazılacak telgraf } \\
\text { üzerine görüşmeler }\end{array}$} \\
\hline 24 & Hasan Efendi & 1 & & & & \\
\hline 25 & Bahri Bey & & 3,8 & & & \\
\hline 26 & Salih Sıdkî Bey & & 3,8 & & & \\
\hline 27 & Süleyman Bey & & 3,8 & & \multirow{5}{*}{$7 / 13$} & \multirow{5}{*}{$\begin{array}{l}10 \text { Eylül } 1919 \\
\checkmark \text { Amerikan Kongresine } \\
\text { yazılacak davet mektubu } \\
\checkmark \text { Millete hitaben yazılacak } \\
\text { beyanname } \\
\checkmark \text { Bütçe oluşturulmasına dair } \\
\text { görüşmeler }\end{array}$} \\
\hline 28 & Ratibzade Mustafa Ef. & & 3,8 & & & \\
\hline 29 & Sami Zeki Bey & & 3 & & & \\
\hline 30 & Mehmet Tevfik Bey & & 3 & & & \\
\hline 31 & Necip Ali Bey & & 8 & & & \\
\hline 32 & Osman Efendi & & 8 & & \multirow[b]{4}{*}{$8 / 26$} & \multirow{4}{*}{$\begin{array}{l}11 \text { Eylül } 1919 \\
\checkmark \text { Yeni Heyet-i Temsiliye } \\
\text { Üyelerinin seçilmesi } \\
\checkmark \text { Bütçe tartışmaları } \\
\checkmark \text { İrade-i milliye gazetesinin } \\
\text { çıkarılması } \\
\checkmark \text { Dört kişilik bir delege } \\
\text { heyetinin Ulu Cami’de } \\
\text { konuşma yapması }\end{array}$} \\
\hline 33 & Hakkı Behiç Bey & & 8 & & & \\
\hline 34 & Şeyh Fevzi Efendi & & & $8^{53}$ & & \\
\hline 35 & Ömer Mümtaz Bey & & & $8^{54}$ & & \\
\hline$\overline{36}$ & Ömer Mümtaz Bey & - & - & - & - & \\
\hline 37 & Kalaçzade Ahmet Hilmi & - & - & - & - & \\
\hline 38 & Katibzade Nuh Naci & - & - & - & - & \\
\hline 39 & Tatlızade Nuri Ef. & - & - & - & - & \\
\hline
\end{tabular}

53 Tutanaklarda Mustafa Kemal Paşa, Şeyh Fevzi Efendi'ye "Refet Bey kardeşimizle Şeyh Efendi Hazretleri de söylemezler mi?" şeklinde hitap etmiştir. Sivas Kongresi Tutanakları, s. 107.

54 Makale metninde izah edildiği üzere belgede Muhtar şeklinde yazılmasına rağmen doğrusu Mümtaz'dır. 
Tablo 2'de delegelerin sayısının yanı sıra isimleri, aile adları ve unvanlarının tespitinde, sadece tutanak ve belgelerde geçtiği yerlerdeki yazım dikkate alınmıştır. Ayrıca delegelerin kongre esnasındaki faaliyetleri ve etkinliklerinin ortaya çıkarılması hedeflenmiştir. $\mathrm{Bu}$ meyanda sadece istatistiki bilgilere, sayılara kesinlik ve anlamlılık hususunda itiraz edilebilir. Ancak bu eleştirinin bir nebze önünü almak adına Sivas Kongresi'ndeki toplantı gündemi, kimlerin ve kaç kişinin konuştuğu veya önerge verdiğine dair bilgiler ortaya konularak, tabloların daha anlamlı olmasına çalışılmıştır.

Diğer taraftan tutanak ve belgelerden hareket ederek ortaya çıkarılan Tablo 2'deki delegelerin ve sayılarının, takribi bir doğruluğa ulaştığı kanaatine varılabilir. Nitekim kongrenin 3. oturumunda Erzurum Kongresi Beyannamesine dair müzakereler esnasındaki bir oylamada, "ekseriyet" sayısının verilmesi önemlidir. Yapılan bu oylamada ekseriyetin 19 kişiyle oluştuğu ifade edilmiştir ${ }^{55}$. Yine kongrenin ilk oturum olmasına rağmen Mustafa Kemal Paşa'nın 26 mevcut delegeden 23'ünün oyunu alarak başkan seçilmesi ${ }^{56}$, kongreye katılan en fazla delege sayısı hakkında bir fikir vermektedir.

\section{Sivas Kongresi Delegeleri ve Temsil Yerleri}

Amasya Tamimi ile her sancağı temsilen "üç kadar" kişinin seçilerek gönderilmesi istenmişti. Bu sayıda delegenin seçimi, Anadolu ve Rumeli'deki Müdafaa-i Hukuk teşkilatlarınca yapılacaktı. Bu meyanda Sivas’ta bir araya gelecek delegeler, halkın örgütleri olan Müdafaa-i Hukuk Gruplarının genel bir kongresini yapmış olacaktı ${ }^{57}$. Ancak arzulanan sayıda delege ve temsil edilen şehir sayısına ulaşıldığını söylemek mümkün değildir. Bununla birlikte delege sayısının, katılımın tasarlananın altında olmasının birçok sebebi vardı. Öncelikle İtilaf Güçleri ve Damat Ferit Paşa Hükümeti, kongrenin yapılmasını engellemek için her türlü çaba içinde olmuştur. Valiler ve Kolordu Kumandanları vasıtasıyla kongrenin engellenmesi için çaba sarf etmişlerdir. Özellikle Elazı ̆̆ Valisi Ali Galip kongreyi engellemek, hatta basarak Mustafa Kemal Paşa'yı tutuklamak istemiştir ${ }^{58}$. Ayrıca kongrenin yapıldığı zaman ve şartlar olağanüstü idi. Nitekim güvenlik ve ulaşım sorunlarının yaşandığ 1 yollarda seyahat zorluğu, delegelerin kongreye katılımını etkilemiştir ${ }^{59}$. Bu yüzden böyle bir dönemde ve engellemelere rağmen toplanılması önemli bir başarıdır.

55 Sivas Kongresi Tutanaklarl, s. 68-69.

56 Salâhattin Kösoğlu’nun Milli Mücadele Hatıralarl, s. 154.

57 Sivas Kongresi Tutanaklarl, s. 7-8.

58 Dâhiliye Nezaretinden Sivas Vilayetine gönderilen 18 Ağustos 1919 tarihli şifre, BOA, DH.ŞFR, 102/183-1; Sivas Vilayetinden Dâhiliye Nezaretine gönderilen 20 Ağustos 1919 tarihli şifre, BOA, DH.ŞFR, 642/122-1, lef 1. Sivas Valisi Reşit Paşa 'nın Hatıraları, s. 41-47, 139-157; Mehmet Arif Bey, a.g.e., s. 31. Sivas Kongresi oturumlarında birçok delege, İstanbul hükümeti ve İtilaf Güçleri baskısı nedeniyle kendi seçimlerinin gizli ve zorluklar altında yapıldığını anlatmışlardır. Sivas Kongresi Tutanakları, s. 24-25, 28.

59 Sivas Kongresi delegelerinin önemli bir kısım Ankara üzerinden Sivas'a geçmişlerdir. Cebesoy, a.g.e., s. 186187. 
Diğer taraftan Sivas Kongresi, Erzurum Kongresi'nden farklı olarak bütün bölgeleri temsilen ve karar almak için toplanmıştı. Bu noktada temsil hususuna tutanaklarda, sadece delege ismi ve şehir sayısı üzerinden yaklaşmak hatalı olacaktır. Zira tutanaklardan oluşturulan Tablo 3 dikkate alındığında, Sivas Kongresi'nde Orta ve Batı Anadolu ağırlıklı şehirlerin temsil edildiği biçiminde bir izlenimle karşılaşılabilir. Ancak bu izlenimin, tutanaklardaki konuşmalar incelendiğinde doğru olmadığı görülecektir. Zira çoğu zaman Mustafa Kemal Paşa ve Erzurum Heyet-i Temsiliyesi üyeleri, kendilerini Karadeniz dâhil, bütün Doğu Anadolu adına Erzurum Kongresi ve kararları uyarınca hareket edenler olarak tavsif etmişlerdir. Nitekim Sivas Kongresi öncesi hazırlıklarını sürdüren "takriben yirmi beş kişilik" heyetin içinden biri olan İsmail Fazıl Paşa, Erzurum'dan gelenleri "Vilayât-1 Şarkiye Delegeleri” olarak isimlendirmiştir ${ }^{60}$. Benzer şekilde Erzurum Kongresi kararlarıyla ilgili görüşmelerdeki değişiklik teklifleri esnasında, Heyet-i Temsiliye üyesi olan Raif Efendi’nin Erzurum Kongresi kararlarının muhafazası noktasında direnmesi ve "Vilayât-ı Şarkiye Heyet-i Temsiliyyesi buraya gelmiştir, burada Vilayât-1 Şarkiye nokta-i nazarını müdafaa edecektir" şeklindeki ifadeleri, temsil meselesine önemli katkı sağlamaktadır ${ }^{61}$. Yine Mustafa Kemal Paşa'nın Heyet-i Temsiliye üye sayısının artırılmasına dair tartışmalarda "zaten Vilayât-1 Şarkiyye mümessilleri kuyud-1 mevcudeye nazaran intihab edilmişlerdir"62 şeklindeki sözleri de temsilin genelliğini teyit etmektedir. Ayrıca Sivas Kongresi, kendi kararlarını içeren beyannamesini hazırlarken Erzurum Kongresi Beyannamesini esas alması, diğer bölgelerin de temsil yönüne işaret etmektedir.

Tutanak ve belgelerle hatıra ve telif eserlerin verdiği delegelerin temsil ettiği şehirlere dair bilgilerde de ciddi farklılıklar bulunmaktadır. Üstelik tutanaklarda delegelerin bazıları birden fazla şehrin temsilcisi olarak gözükmektedir. Bu durumun neden kaynaklandiğ üzerinde durulmalı ve tartışılmalıdır. Bu minvalde Osmanlı seçim kanununa göre Meclis-i Mebusan seçimlerinde birden fazla sancaktan adaylar gösterebildiği bilinmektedir. Ancak seçilerek mebus sıfatını alan aday, seçildiği şehirlerden birini tercih etmek zorunda idi. Tutanaklarda Denizli delegesi olarak görünen Mazhar Müfit Bey, ayrıca Ankara ve Aydın; Miralay Vasıf Bey, Antep ve Afyonkarahisar'1 da temsil etmekteydi ${ }^{63}$. Bu husus, kongreye katılımın zorluğundan kaynaklanan sorunları çözme şekli olarak değerlendirilebilir.

Delegelerin temsil durumlarıyla ilgili olarak üzerinde durulması gereken bir husus daha vardır. Aslında bütün çalışmalarda bu durum mevcut olmasına rağmen üzerinde durulmamıştır. Delegelerin hemen hepsi şehirlerin temsilcisi olarak gözükmektedir. Zaten yukarıda ifade

60 Sivas Kongresi Tutanaklarl, s. 48.

61 Sivas Kongresi Tutanaklarl, s. 63.

62 Sivas Kongresi Tutanaklarl, s. 71.

63 Toparl1, Sivas Kongresi Tutanaklart ve Belgeleri, s. 506. Mazhar Müfit Kansu tutanak ve belgelerde Denizli, Aydın, Ankara temsilcisi olarak görünmektedir. Ancak kendi hatıratında belirttiği ve valilik yaptığı bölgede bulunan Hakkâri şehrine rastlanılmamıştır. Kansu, a.g.e., I, s. 252. 
edildiği üzere Amasya Tamimi’ne göre delegeler sancaklardan seçilerek Sivas'a geleceklerdi. Ancak bütün kaynaklarda ve tutanaklarda adı bulunan Hikmet Bey, Tıbbiye temsilcisi olarak gösterilmektedir ${ }^{64}$. Bu durum bir istisna şeklinde değerlendirilmemelidir. Nitekim bu çalışmada delege listesine alınan 3. Kolordu Kumandanı Selahattin Bey, Askeriye temsilcisi kategorisinde sayılmalıdır. Dolayısıyla bu iki örnek, şehirlerin dışında bazı meslek gruplarının da Sivas Kongresi'nde temsil edildiğine dair tartışmalara kapı araladığg kanaatindeyiz.

\begin{tabular}{|c|c|c|c|c|}
\hline \multicolumn{5}{|c|}{$\begin{array}{c}\text { Tablo } 3 \\
\text { Sivas Kongresi Delegelerinin Temsil ve Mesleki Durumları }\end{array}$} \\
\hline 层 & İSIM & $\begin{array}{l}\text { Tutanak ve Belgelerde } \\
\text { Şehir/Temsil }\end{array}$ & $\begin{array}{l}\text { Diğer Kaynaklarda } \\
\text { Şehir/Temsil }\end{array}$ & Meslek/Görev ${ }^{65}$ \\
\hline 1 & Mustafa Kemal Paşa & Erzurum $^{66}$ & \begin{tabular}{|l|} 
Erzurum \\
Heyeti-i Temsiliye
\end{tabular} & Müstafi Ordu Müfettişi \\
\hline 2 & Hoca Raif Efendi & Erzurum & \begin{tabular}{|l} 
Erzurum \\
Heyeti-i Temsiliye
\end{tabular} & Ulema \\
\hline 3 & Rauf Bey & Sivas $^{67}$ & Heyeti-i Temsiliye & Eski Bahriye nazırı \\
\hline 4 & Bekir Sami Bey & Sivas & $\begin{array}{l}\text { Tokat } \\
\text { Heyeti-i Temsiliye }\end{array}$ & Eski Beyrut Valisi \\
\hline 5 & İsmail Fazıl Paşa & İstanbul & İstanbul & Eski Ferik \\
\hline 6 & Osman Nuri Bey & Bursa & Bursa & Avukat \\
\hline 7 & Ahmed Nuri Bey & Bursa & Bursa & Eski Bursa Belediye Başkanı \\
\hline 8 & Hakkı Behiç Bey & Bursa & Eskişehir, Denizli & Muharrir \\
\hline 9 & Halil İbrahim Ef. & Eskişehir & Eskişehir & Taşocakları Sahibi \\
\hline 10 & Hüseyin Bey & Eskişehir & Eskişehir & --- \\
\hline 11 & Hüsrev Sami Bey & Eskişehir & Eskişehir & $\begin{array}{l}\text { Eski Ankara Mebusu/Topçu } \\
\text { Yüzbaş//Tüccar }\end{array}$ \\
\hline 12 & Mehmed Şükrî Bey & Karahisar-1 Sahip ${ }^{68}$ & Afyonkarahisar & Tüccar/İkaz Gazetesi Sahibi \\
\hline 13 & Salih Sıdkî Bey & Karahisar-1 Sahib & Afyonkarahisar & \\
\hline 14 & Miralay Vasif Bey & Ayıntab, Karahisar-1 Sahib & İstanbul, Gaziantep & $\begin{array}{l}\text { Emekli Erkan-1 Harbiye } \\
\text { Miralay1 }\end{array}$ \\
\hline 15 & Mazhar Müfid Bey & Denizli, Aydın, Ankara & Hakkâri & Eski Bitlis Valisi \\
\hline 16 & Yusuf Bey & Denizli & Denizli & Ziraatçı \\
\hline 17 & Mehmed Şükri Bey & Denizli & Denizli & $\begin{array}{ll}-- \\
-\end{array}$ \\
\hline 18 & Necip Ali Bey & Denizli & Denizli & Hukuk Talebesi \\
\hline 19 & İbrahim Süreyya Bey & Alaşehir, Karesi & Karesi & Eski Karesi Mutasarrıfi \\
\hline 20 & Macid Bey & Alaşehir & Alaşehir & Tüccar \\
\hline 21 & Abdurrahman Tosun B. & Çorum & Çorum & İdadi Muallimi \\
\hline
\end{tabular}

64 Sivas Kongresi Tutanaklarl, s. 68.

65 Delegelerin meslekleri ve görevlerine dair bilgiler çoğunlukla hatıra ve telif eserlerden derlenmiştir.

66 Mustafa Kemal Paşa ve Hoca Raif Efendi'nin temsil ettiği şehir doğrudan doğruya Erzurum yazmamakla birlikte konuşmalarında doğu bölgelerinin temsilcisi olduklarını sıç̧a ifade etmişlerdir. Buna istinaden temsil ettikleri şehir olarak Erzurum yazılmıştır.

67 Sivas Müdafaa-i Hukuk Cemiyeti Bekir Sami Bey’e bir dilekçe vererek, kongre müzakerelerine dinleyici olarak girmek istemişlerdir. Bunun üzerine Mustafa Kemal Paşa, Sivas "halkının mümessillerinin” Rauf Bey ve Bekir Sami Bey olduğunu ifade etmiştir. Sivas Kongresi Tutanakları, s. 26-28.

68 Tutanaklarda Afyonkarahisar, bazen Karahisar, Karahisar-1 Sahib şeklinde de yazılmıştır. 


\begin{tabular}{|c|c|c|c|c|}
\hline 22 & Mehmet Tevfik Bey & Çorum & Çorum & İhtiyat Zabiti \\
\hline 23 & Osman Efendi & Nevşehir & Nevşehir & --- \\
\hline 24 & Ratibzade Mustafa Ef. & Niğde & Niğde & Tüccar \\
\hline 25 & Halid Hami Bey & Bor & Bor, Niğde & Bor Mal Müdürü \\
\hline 26 & Sami Zeki Bey & Kastamonu & Kastamonu & Emekli Binbaşı \\
\hline 27 & Bahri Bey & Yozgat & Yozgat & Tüccar/Zürra \\
\hline 28 & Süleyman Bey & Samsun & Samsun, Canik & Tüccar \\
\hline 29 & Hikmet Bey & T1bbiye & Tibbiye & Tıp Fakültesi Öğrencisi \\
\hline 30 & Ömer Mümtaz Bey & Ankara & Ankara & $\begin{array}{l}\text { Eski Ankara Mebusu/ } \\
\text { Mutasarrıf }\end{array}$ \\
\hline 31 & Selahattin Bey & Askeriye $^{69}$ & --- & 3. Kolordu Kumandanı \\
\hline 32 & Emir İsmail Hami Bey & -- & İstanbul & $\begin{array}{l}\text { Muharrir (Memleket ve } \\
\text { İrade-i Milliye) }\end{array}$ \\
\hline 33 & Şeyh Fevzi Efendi & -- & $\begin{array}{l}\text { Erzincan } \\
\text { Heyeti-i Temsiliye }\end{array}$ & Nakşibendi Tarikatı Şeyhi \\
\hline 34 & Refet Bey & --- & Ankara, Canik & Kolordu Kumandanı \\
\hline 35 & Hasan Efendi & --- & --- & --- \\
\hline 36 & Ömer Mümtaz Bey & --- & Kayseri & Eski Kayseri Mebusu \\
\hline 37 & $\begin{array}{l}\text { Kalaçzade Ahmet } \\
\text { Hilmi }\end{array}$ & -+- & Kayseri & $\begin{array}{l}\text { Eski Kayseri Mebusu/ } \\
\text { Mutasarrıf }\end{array}$ \\
\hline 38 & Katibzade Nuh Naci & --- & Kayseri & Tüccar \\
\hline 39 & Tatlızade Nuri Ef. & --- & Kastamonu & --- \\
\hline
\end{tabular}

\section{Sonuç}

Sivas Kongresi ve kararlarının başarısı, sadece Anadolu'daki işgallere karşı gelen direniş hareketlerini belli bir program ve teşkilatlanma ile tek bir yönetim merkezi altında birleştirmesiyle öne çıkmamıştır. Aynı zamanda İstanbul'un dışında yeni bir iktidar merkezi olma özelliği de göstermiştir. Bu özelliğini ise yüzyılın ve Osmanlı Devleti'nin en son geldiği siyasi tarihin ve tecrübenin meşruiyetine dayandırmıştır. Nitekim Sivas Kongresi delegeleri, tutanaklarda sıkça karşılaşıldığg üzere milletin temsilcileri olarak millet adına yola çıktıklarını ifade etmişlerdir. Bu yüzden siyaseten mücadele metodunu benimseyen İstanbul merkezli iktidar, Sivas Kongresi’nin toplanmasını engellemek, dağıtmak ve lider kadrosunu ve delegelerini tutuklamak için her türlü vasıtaya tevessül etmiştir.

Sivas Kongresi'nin kazandığı bu görüntü, Türkiye Cumhuriyeti Devleti’nin tarihi açısından kongre delegelerini çok önemli ve değerli kılmaktadır. Nitekim Sivas Kongresi, Türkiye Cumhuriyeti tarihine dair çalışmalarda sıkça ve üzerinde önemle durulan bir konu olmuştur. Doğrudan doğruya Sivas Kongresi ve delegeleri üzerine yapılan bu tür çalışmalarda çoğu kez hatıralar kullanılmıştır. Ancak hatıralar, delegelerin tespiti açısından birbirinden farklı, hatta çelişkili, sorunlu noktaları içinde barındırmaktadır. Bu yüzden Sivas Kongresi

69 Bu sınıflandırma çalışma sonucu ulaşılan bilgiler çerçevesinde belirlenmiştir. 
delegelerinin kimler ve kaç kişi olduğuna, hangi bölgeleri temsil ettiğine dair hususlar, bilimsel çalışmaların konusu ve tartışması halindedir. Aslında bu tartışmaların yanına oturumlarda konuşulan ve karara bağlanan noktalarda, millet adına hareket eden delegelerin katılımı da önemli olmalıdır.

$\mathrm{Bu}$ noktalardan hareketle bu çalışmanın içeriğinin oluşturulmasında, kongre esnasında konuşma, önerge verme ve adı geçme ölçütleri çerçevesinde Sivas Kongresi'nin Osmanlı Türkçesi ile kayıt altına alınmış orijinal tutanak ve belgeleri dikkate alınmıştır. Bunun yanı sıra çalışmanın içeriğini anlaşılır kılma gerekçesiyle bazı tablolar oluşturularak, üzerinde durulması gerektiğine dair ifade ettiğimiz noktalara bir nebze katkı sağlanmak istenmiştir. Bununla birlikte varılan sonuç; farklı soru ve yaklaşımlar, mevcut ve muhtemel yeni kaynaklar üzerinden hareketle geliştirilmelidir.

Diğer taraftan orijinal tutanaklar kendi içinde de bazı sorunları barındırmaktadır. $\mathrm{Bu}$ manada tutanakların genelinde, oturumlarda veya bütün kongre boyunca katılan delege ve toplantı yeter sayısına dair oldukça açık bir bilgiye rastlanmamaktadır. Bununla birlikte tutanaklarda konuşmacı ve önerge sahiplerinin gerek isimlerinin ve gerek temsil şehirlerinin kaydedilmesi genel bir değerlendirme ve istatistik vermeye imkân tanımaktadır. Özellikle dönemin hatıraları ve telif eserlerdeki eksik ve hataları görmeye firsat vermektedir. $\mathrm{Bu}$ meyanda bazı çalışma ve hatıralarda 30'u bulmayan delege sayısı, konuşma, takrir verme ve adı geçme ölçütleri çerçevesinde net bir şekilde 35'e çıkarılabilmiştir. Örneğin 3. Kolordu Kumandanı Salahattin Bey'i ve hakkında bilgi bulunmayan Hasan Efendi'yi, birçok çalışmanın aksine eklemek mümkün olmuştur.

Benzer şekilde birkaç kişi haricinde delegelerin temsil yerine dair orijinal tutanak ve belgeler çerçevesinde kesin bilgiye ulaşılmıştır. Bu noktada, ayrıca şehir dışında yeni bir temsil tasnifinin de üzerinde durulması gerektiği tartışmaya açılmıştır. $\mathrm{Bu}$ araştırma istatistiki bilgilerin dışında, aslında çalışmaların içeriğinin de çok önemli olduğunu bir kez daha göstermiştir. Zira bu çalışma metninin içinde gösterilen istatistiki bilgilerden elde edilen sayıların yanı sıra başka hususlar da ortaya konulmuştur. Bu meyanda Sivas Kongresi'nin temsil gücünün Erzurum Kongresi ile birlikte değerlendirilmesi gerektiği bir kez daha gözler önüne serilmiştir. Nitekim Erzurum Kongresi'nde seçilen ve Anadolu Hareketi'nin yürütme organı hüviyetini taşıyan Heyet-i Temsiliye üyeleri, kendilerinin Erzurum Kongresi'ni, dolayısıyla çok daha geniş bir coğrafyayı temsil ettiklerini mütemadiyen zikretmişlerdir. Bu noktada unutulmaması gereken husus, genelliğe vurgu yapan "Vilayât-1 Şarkiye" ifadesinin yanı sıra, bu bölge delegelerinin kendi şehirlerinin temsilcisi olduklarıdır. Nitekim Heyet-i Temsiliye üyesi olan Rauf Bey ve Bekir Sami Bey’in, tutanaklarda Mustafa Kemal Paşa tarafından Sivas şehrini temsil ettiği, ayrıca vurgulanmıştır. 
Hakem Değerlendirmesi: Dış bağımsız.

Çıkar Çatışması: Yazar çıkar çatışması bildirmemiştir.

Finansal Destek: Yazar bu çalışma için finansal destek almadığını beyan etmiştir.

Peer-review: Externally peer-reviewed.

Conflict of Interest: The author has no conflict of interest to declare.

Grant Support: The author declared that this study has received no financial support.

\section{Kaynakça/References}

\section{Arşiv Kaynakları}

\section{Türkiye Cumhuriyeti Cumhurbaşkanlığı Devlet Arşivleri Başkanlığı Osmanlı Arşivi (BOA)}

Bâb-1 Ali Evrak Odası (BEO)

Dahiliye Nezareti

Kalem-i Mahsus (DH.KMS)

Şifre Kalemi (DH.ŞFR)

Hariciye Nezareti Siyasi Kısım (HR.SYS)

Meclis-i Vükela (MV)

\section{Resmi Yayınlar}

MM Zabıt Ceridesi

\section{Hatıra ve Araștırmalar}

4 Eylül 1919 Sivas Kongresi Tutanak ve Belgeleri, (Yoğun CD) Haz. Kadir Pürlü, Sivas İl Kültür Müdürlüğü, Sivas 2009.

Akandere, Osman, "Milli Mücadelenin Başlarında Mustafa Kemal Paşa Sine-i Millet Düşüncesi ile Askerlikte İstifa Öncesi ve Sonrası Kendisine Gösterilen Bağlılıklar”, Selçuk Üniversitesi Türkiyat Araştırmaları Dergisi, Say1 11, Konya 2002, s. 247-309.

Aşkun, Vehbi Cem, Sivas Kongresi, İstanbul 1963.

Atatürk, Mustafa Kemal, Nutuk, I, III, MEB, İstanbul 1993.

Bostanc1, Mustafa, "Milli Mücadelede Erzurum Kongresi ve Kararları”, Nevşehir Hacı Bektaş Veli Üniversitesi Sosyal Bilimler Enstitüsü Dergisi, 4 (2015), s. 184-203.

Bozkurt, Abdurrahman, İtilaf Devletlerinin İstanbul'da İşgal Yönetimi, ATAM, Ankara 2014.

Cebesoy, Ali Fuat, Milli Mücadele Hatıraları, Temel Y., İstanbul 2000.

Denizli, Hikmet, Sivas Kongresi Delegeleri ve Heyet-i Temsiliye Üyeleri, Kültür Bakanlığı Y., Ankara 1996.

Goloğlu, Mahmut, Erzurum Kongresi, Ankara 1968. , Sivas Kongresi, Başnur Matbaası, Ankara 1969.

Günaydın, Ahmet Necip, Milli Mücadelede Sivas-108 Gün (2 Eylül-18 Aralık 1919), 3. Bask1, Sivas Vilayet Kitaplı̆̆ 1 , Sivas 2019. 
İğdemir, Uluğ, Sivas Kongresi Tutanaklarl, 3. Baskı, TTK, Ankara 1999.

İkinci Grup'un Kurucularından Salâhattin Kösoğlu’nun Milli Mücadele Hatıralarl, haz. Ahmet Demirel, İletişim, İstanbul 2017.

Kansu, Mazhar Müfit, Erzurum'dan Ölümüne Kadar Atatürk’le Beraber, I, TTK, Ankara 1988.

Kılıç, Selami, “Mustafa Kemal (Atatürk) ve Erzurum Kongresi”, Atatürk Dergisi, II, sayı 1, Erzurum 1997, s. 77-97.

Kılıç, Selda, “1876 Meclis-i Mebusanı ve Seçim Hazırlıkları”, OTAM sayı 30 (2011), s. 27-40.

Milli Egemenlik Belgeleri, TBMM Yayınları, Ankara 2015.

Miralay Mehmet Arif Bey, Anadolu İhtilali-Milli Mücadele Anılart- (1919-1923), yay. haz. Bülent Demirbaş, Arba, İstanbul 1987.

Sancaktar, Fatih M., “Mondros Mütarekesi'nin 20. Maddesi ve İtilaf Güçlerinin Çatalca ve İstanbul Boğazı'ndaki Osmanlı Askeri Mühimmatını İmha veya Satma Girişimlerine Osmanlı Devleti'nin Engel Olma Çabası", Imparatorluklar Çağına Veda, ed. Süleyman Beyoğlu, Bülent Bakar, Okan Yeşilot, Ötüken, İstanbul 2018, s. 255-283.

, “Türkçe İstanbul Gazetesinin Osmanlı Devleti Üzerinde kurulacak Bir Himaye İdaresine Örnek

Bulma Çabası', Illkadım 'dan Cumhuriyet'e Milli Mücadele, ed. Osman Köse, İstanbul 2008, s. 181-190.

Sivas Valisi Reşit Paşa'nın Hatıraları, İstanbul t.y.

Tanör, Bülent, Türkiye’de Kongre İktidarlarl (1918-1920), YKY, İstanbul 1998.

Toparl1, Recep, Sivas Kongresi Belgeleri, Sivas Vilayet Kitaplı̆̆1, Sivas 2015.

, Sivas Kongresi Tutanakları ve Belgeleri, Cumhuriyet Üniversitesi Sivas Araştırma ve Uygulama Merkezi Yayınları, Sivas 2014. , Sivas Kongresi Tutanakları, Sivas Vilayet Kitaplı̆̆ı, Sivas 2015.

Ural, Selçuk, “İngiltere'nin Mondros Mütarekesi’nin 20. Maddesi'ne Aykırı Uygulamaları”, Ankara Üniversitesi Türk Inkllap Tarihi enstitüsü Atatürk Yolu Dergisi, sayı 44, Güz 2009, s. 713-742.

Yazıcı, Sibel, Osmanlı Meclis-i Mebusanı ve Faaliyetleri (1914-1918), Yayınlanmamış Doktora Tezi, Afyonkarahisar 2018. 


\section{Ek 1}

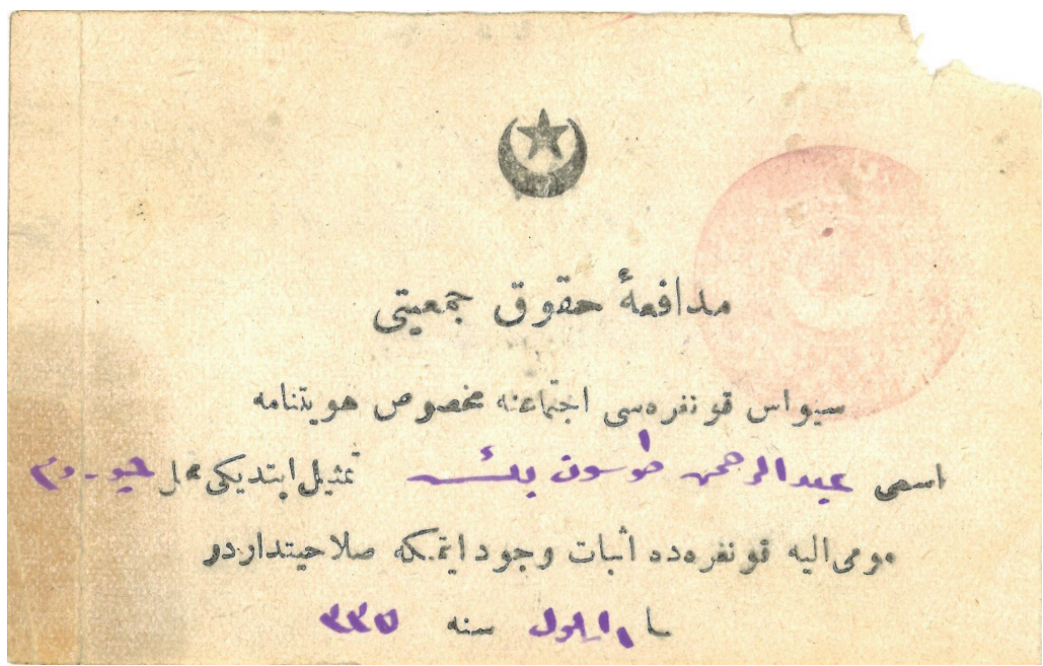

Müdafaa-i Hukuk Cemiyeti

Sivas Kongresi İçtimaina Mahsus Hüviyetname İsmi Abdurrahman Tosun Bey Temsil Ettiği Mahal Çorum Mumaileyh Kongrede İsbat-1 Vücud Etmeğe Salahiyetdardır Fi 1 Eylül Sene 1335

\section{Türk Tarih Kurumu Kütüphanesi}




\section{Ek 2}

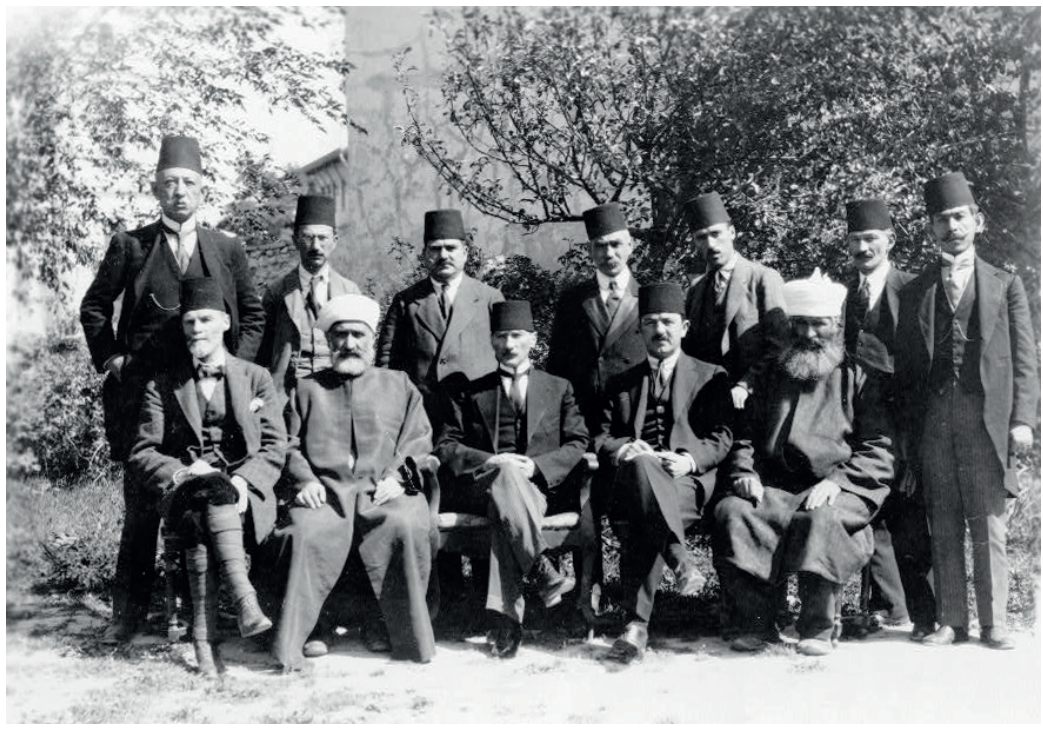

Sivas Kongresi Günlerinde Heyet-i Temsiliye Üyeleri 